\title{
Austerity, Assistance and Institutions: Lessons from the Greek Sovereign Debt Crisis
}

\section{George Economides ${ }^{1,2}$. Dimitris Papageorgiou ${ }^{3} \cdot$ Apostolis Philippopoulos $^{2,4}$}

Accepted: 8 December 2020 / Published online: 29 March 2021

(C) The Author(s), under exclusive licence to Springer Science+Business Media, LLC part of Springer Nature 2021

\begin{abstract}
This paper studies the Greek sovereign debt crisis in the aftermath of the 2007-8 global financial crisis looking for barriers to, and engines of, growth. The vehicle is a calibrated medium-scale micro-founded macroeconomic model. Departing from 2008, our simulations show that the adopted economic adjustment program (the fiscal austerity mix combined with the fiscal and monetary assistance provided by the EU, ECB and IMF), jointly with the observed deterioration in institutional quality (the degree of protection of property rights) can explain most (around 22\% of GDP) of the cumulative loss in GDP in the data (around 26\% of GDP) between 2008 and 2016. In particular, the economic adjustment program can explain a fall of around $12 \%$, while the deterioration in property rights accounts for another $10 \%$. Counterfactual simulations, on the other hand, show that this loss could have been around $9 \%$ only, if the country had followed a different fiscal policy mix; if the degree of product marker liberalization was closer to that in the core euro zone countries; and, above all, if institutional quality in Greece had simply remained at its pre-crisis level. On the other hand, in the absence of the official fiscal bailouts, the depression would be much deeper, while, the accommodative role played by the quantitative policies of the ECB has been vital to the Greek economy. These results can be useful in the face of the ongoing covid-19 crisis.
\end{abstract}

Keywords Growth $\cdot$ Macroeconomic policy $\cdot$ Institutions

JEL Classification O4 · H6 · E02

Apostolis Philippopoulos

aphil@aueb.gr

1 Department of International and European Economic Studies, School of Economics, Athens University of Economics and Business, 76 Patission street, Athens 10434, Greece

2 CESifo, Munich, Germany

3 Bank of Greece, Athens, Greece

4 Department of Economics, School of Economics, Athens University of Economics and Business, 76 Patission street, Athens 10434, Greece 


\section{Introduction}

Among the euro zone (EZ) periphery countries hit by the global financial crisis of 2007-8, Greece experienced the worst decline and the biggest need for international support. ${ }^{1}$ Between 2008 and 2016, Greece lost more than one fourth of its GDP. It also had to rely on a number of official or unofficial programs of financial assistance provided in various forms by the EU, the ECB and the IMF. Although GDP growth managed to rebound in 2017 , the recovery was fragile (driven mainly by net exports and private consumption) even before the eruption of the new economic crisis triggered by the covid-19 shock in early 2020 . For instance, at the end of 2019, private investment remained at around $11 \%$ of GDP only, public debt was around $175 \%$ of GDP, external liabilities were around $140 \%$ of GDP, unemployment was around $17 \%$ and, perhaps more importantly, Greece scored poorly in institutional quality vis-àvis other EU and OECD countries. ${ }^{2}$ Besides, as part of the various bailout programs, around $70 \%$ of Greek public debt is owned by public institutions of the EU and the ECB.

Aim of this Paper The aim of this paper is threefold. First, we search for the drivers of the Greek sovereign debt crisis. This includes driving forces and propagation mechanisms through which the driving forces shaped equilibrium outcomes and in particular the big output loss between 2008 and 2016. Second, we conduct a decomposion exercise to quantify the relative contribution of various driving forces, as they are in the data, to this output loss. Third, building upon the first two steps, we search for counter-factual policy scenaria that could have possibly given better outcomes between 2008 and 2019. Putting all this together, our main aim is to identify the barriers to, and the engines of, growth. This helps us to draw some policy lessons that could also be useful in the face of the new challenges posed by the ongoing covid-19 pandemic crisis. $^{3}$

A Brief Recollection of Events To place our work in context, we need to recall the key events in Greece over the euro period. The Greek sovereign debt crisis should not have come as a surprise; it had all the symptoms of a typical international crisis (see e.g. Lorenzoni (2014)). Greece was already in imbalance when the global financial

\footnotetext{
${ }^{1}$ For the Greek crisis, see e.g. Sinn (2010, 2014), Ioannides and Pissarides (2015), De Grauwe (2016), Alesina et al. (2019, chapter 8), Tavlas (2019) and Alogoskoufis (2019). For econometric studies, see e.g. Gibson et al. (2015, 2019). For DSGE models, see e.g. Arellano and Bai (2016), Gourinchas P-O et al. (2017), Papageorgiou and Vourvachaki (2017), Economides et al. (2017), Glomm et al. (2018), Dellas et al. (2017) and Chodorow-Reich et al. (2019). See also the papers in the volumes edited by Meghir et al. (2017) and Bournakis et al. (2017). See below for details and how our work differs.

${ }^{2}$ In Greece, weak institutions are captured by various indices measuring the poor enforcement of the law, vandalism and violence, an inefficient public administration, a labyrinth of bureaucracy, a slow judicial system, laws and regulations that limit competition, tax evasion, poor education (PISA) scores, etc. For institutional quality in Greece relative to other countries, see e.g. Papaioannou (2016), Masuch et al. (2018), Kollintzas et al. (2018) and Christou et al. (2020). See below for data and details.

${ }^{3}$ When the heath crisis is over, and the Greek economy restarts, it will probably be in a situation similar to that at the start of the sovereign debt crisis twelve years ago: economic stagnation combined with a severe sovereign debt burden.
} 
crisis erupted in 2007-8. From the late 1990 s to 2008 , the country enjoyed an exceptional economic boom and declining unemployment. But this was driven by a big rise in private demand and pro-cyclical fiscal policies, both of which were financed by borrowing from optimistic banks in Greece and Northern Europe. The demanddriven boom led to accumulation of large private, public and external debts. It also led to rises in wages, prices and unit labor costs and hence to losses in competitiveness. In addition, and perhaps this went unnoticed, Greece displayed a big asymmetry in institutional quality (as described above) relative to its EU partners. Then, in 2009, amid an unfavorable environment (the "sudden" recognition of the above imbalances, unpleasant news about the country's public finances, big riots in Athens in December 2008 combined with political polarization, the release of reports by the European Commission and rating agencies expressing fears of sovereign insolvency, etc), confidence was undermined, expectations were reversed, GDP collapsed, debts-to-GDP exploded, and all this became a vicious cycle. Greece, along with Ireland and Portugal, was shut out from private capital markets and the Greek government had to resort to its first official fiscal bailout provided by the EU and the IMF in early 2010. Nevertheless, the fear of default rose again, insolvency was admitted by all and, in 2012, the Greek government defaulted on its bonds held by private creditors. But again this was not enough. Greece had to receive two more official fiscal rescue loans provided by other EU states, EU institutions (EFSF, EFSM, ESM) and the IMF in 2012 and 2015. At the same time, and this has been since the very beginning of the global financial crisis, the ECB provided a plethora of supportive quantitative, or balance-sheet, policies (e.g. direct or indirect intervention in the market for Greek government bonds; the support of private banks through a full allotment lending policy, the relaxation of collateral requirements and the provision of ELA; the issuance of cross-border liquidity that compensated for abrupt private capital inflows and known as TARGET2 liabilities; etc). All this complex financial (fiscal and monetary) assistance was offered at much more favorable terms than markets would have imposed on Greece. On the other hand, it was conditioned on a severe fiscal austerity plan monitored by the EC, the ECB and the IMF. Although the real motives behind the financial assistance, as well as the rationale of severe fiscal austerity, have been lively debated (see e.g. Alesina et al. (2019, chapter 8)), this so-called Economic Adjustment Program, combining austerity and assistance, enabled Greece to remain in the euro area. However, fiscal austerity and economic depression, fuelled by political polarization and populism, were associated with a further worsening of institutional quality. The latter is reflected into indices measuring, for example, the rule of law, regulatory quality, and political instability and violence, which show a sharp deteriorarion during the debt crisis years. Notably, these are the indices typically used to construct measures of the degree of protection of property rights and, as is widely recognized, property rights shape incentives and are fundamental drivers of sustainable growth. ${ }^{4}$ Finally, after a difficult decade, Greece exited its Economic Adjustment Program in August 2018 but, as said above, its moderate recovery path that started in 2017 has been abruptly disrupted by the pandemic shock in early 2020 .

\footnotetext{
${ }^{4}$ For the key importance of property rights among other measures of institutional quality, see e.g. Acemoglu (2009, chapter 4), Besley and Persson (2009), Besley and Ghatak (2010) and many others.
} 
Model Our model will try to embed most of the above distinct features of the Greek economy. The vehicle of analysis is a medium-scale micro-founded macroeconomic model of a small open economy participating in a currency union. In addition to a number of real and nominal frictions commonly used by the quantitative macroeconomic literature, the model incorporates, in an attempt to mimic the Greek case, a rather detailed public sector including public employees as a separate income class; problems of institutional quality in the form of ill-defined property rights that trigger anti-social activities; the possibility of sovereign debt default; and international financial (fiscal and monetary) assistance combined with fiscal austerity. To understand better the menu of macro policy instruments used, we model separately the Treasury (fiscal authority) and the national central bank participating in the Eurosystem (monetary authority). In other words, the model incorporates the main ingredients of the Economic Adjustment Program as described above, namely, fiscal austerity combined with international financial assistance, where the latter includes the official fiscal bailouts as well as balance-sheet monetary policies by the Eurosystem. The revenue from the official fiscal bailouts partly make up for the loss of government revenue from being shut out from private capital markets and this happens at non-market interest rates. At the same time, financial frictions (modeled as in Curdia and Woodford (2011)), as well as the issuance of TARGET2 liabilities as part of the monetary base of the national central bank (as studied by Sinn and Wollmershauser (2012), Sinn (2014) and Whelan (2014, 2017)), provide the channels through which quantitative, or balance sheet, monetary policies, as allowed by the ECB, can have real effects and thus work like the official fiscal bailouts. An informal description of the model is in Section 2.1.

Main Results Our simulations show that the Economic Adjustment Program (namely, the fiscal austerity mix combined with the official fiscal bailouts and the various types of monetary accommodation provided by the ES), jointly with developments in institutional quality (specifically, the deterioration of protection of property rights), can account for most of the cumulative loss in GDP between 2008 and 2016. In particular, departing from 2008, when we feed our model with the Economic Adjustment Program and an index of property rights, both as recorded in the data, the model, via its propagation mechanisms, produces around $22 \%$ fall in GDP between 2008 and 2016 as compared to around 26\% in the data. The Economic Adjustment Program accounts for $12 \%$ and the deterioration in property rights adds another $10 \%$.

On the other hand, counterfactual scenarios during the debt crisis imply the following. First, things could have been much worse. Despite the conflicting views about the content of the bail-out program, especially regarding its fiscal austerity preconditions, our numerical simulations imply that financial assistance (provided by other EU counties and institutions, the ECB and the IMF) has helped the Greek economy to avoid the worst. For instance, if the fiscal needs were financed by, say, higher income taxes rather than by the three official fiscal bailouts, the loss in output would have been tremendous, other things equal. Also, even if one is willing to make the unrealistic assumption that the Greek government were able to keep selling its bonds to the private market, the high market interest rates it would have to pay would have led 
to a bigger output loss than that in the data. Besides, when we make the assumption that the ECB did not follow an accommodative monetary policy towards Greece, the model ceases to exhibit a (stable) solution implying (to the extent that one trusts our model) that this scenario would be nonfeasible, other things equal. Second, things could also have been better. The output loss could have been significantly smaller if some things had been done slightly differently. In particular, the output loss during 2008 and 2016 could have been around 9\% only (always relative to the departure year of 2008), if the country had followed an alternative fiscal policy mix (for example, a cut in income taxes, or an increase in public investment, both financed by a cut in tranfer payments), if reforms in the product market had been adopted and implemented in a faster and/or more effective way so as the degree of product market liberalization to get closer to that in the core EZ countries; and, above all, if institutional quality had not deteriorated since 2008 but had simply remained at its pre-crisis level. It has to be emphasized that improvements in these areas did not have to be in the area of fantasy; in our counterfactuals, we assume small changes vis-a-vis the values in the data. That is, small changes could have made things much better.

Related Literature and How we Differ As already mentioned, there has been a rich literature on the Greek debt crisis. Papers close to ours, which have also used microfounded macroeconomic models, include Arellano and Bai (2016), Gourinchas P-O et al. (2017), Papageorgiou and Vourvachaki (2017), Economides et al. (2017), Glomm et al. (2018), Dellas et al. (2017) and Chodorow-Reich et al. (2019). A common finding of most of these papers, which is also a result shared by our work, is that roughly half of the loss in output between 2008 and 2016 is explained by the fiscal austeriry package adopted.

Our work enriches this literature along several dimensions. One key difference is the way we model economic policy. Here, we take a more balanced view by taking into account, not only the costs of fiscal austerity as the above papers have done, but also the role, and the potential benefits, of international financial assistance, where the latter has been both fiscal (fiscal bailouts) and monetary (ECB support) as well as both explicit (e.g. official rescue programs) and implicit (e.g. TARGET2 liabilities). We do so because one cannot study fiscal austerity without taking into account the other side of the coin which is international financial assistance; as said, the former was the precondition for the latter in the economic adjustment program agreed between Greece and its creditors. We also study the role of the deterioration in institutional quality that occured at the same time and has been triggered by the fiscal austerity measures (and further fuelled by populism from several political sides). Another difference is that several of the above papers, especially Gourinchas P-O et al. (2017), Economides et al. (2017) and Chodorow-Reich et al. (2019), employ a large menu of shocks to explain the crisis, including shocks to TFP, to interest rates on public debt, to default rates, to banks' funding costs, etc. Here, by contrast, most of these variables are endogenously determined. In our paper, when we study the debt crisis, there are two driving forces only (the time-paths of the economic adjustment program and an index of institutional quality, both as recorded in the data), and then the propagation mechanisms of our model provide the channels through which these two driving forces shape macroeconomic and distributional outcomes. 
For example, to the extent that weak property rights distort private incentives leading to resource misallocation, this distortion shows up as an adverse productivity shock endogenizing the effective TFP. Putting all this together, despite a lively debate on the role of financial assistance and institutional quality in policy circles, there have not been theoretical general equilibrium models tailored to study these issues in a unified framework; our paper tries to fill this gap.

But our work is more than a country study. We also contribute to the literature on the nexus among fiscal, public finance and balance-sheet monetary policies. And we do so in the context of an open economy being a member of a currency union like the EZ. Most of the related papers, reviewed in Section 2.6 below, have studied this debated nexus in the context of a closed economy, mainly the US. On the other hand, the models used by the ECB have focused on the link between private banks and the ECB staying away from fiscal financing needs (see e.g. Coenen et al. (2018)). Here, by contrast, building on this literature, as well as on the work by Reis $(2013,2017)$ and Sinn (2014), we study how balance sheet monetary policies can affect fiscal and country resources in a model that exhibits the key features of the Eurosystem. We show that the role of the ECB in the Greek debt crisis was vital.

Layout The rest of the paper is organized as follows. The model is in Section 2. Parameterization, data and the solution for the year 2008 are in Section 3. Departing from this solution, Section 4 presents positive results over 2008-2019, while counterfactuals are in Section 5. Section 6 closes the paper. An Appendix contains algebraic and data details (this appendix is available online).

\section{A Macroeconomic Model for Greece}

In this section, we construct a micro-founded macroeconomic model for the Greek economy during the euro period. We start with an informal description of the model.

\subsection{Informal Description of the Model}

Although we cannot include all details and capture the complexity of reality as sketched in the previous section, we will at least try to construct a model that embeds the key features of the Greek economy. To do so, we add a number of frictions to a standard small open economy model. These frictions are of two categories. The first category includes real and nominal frictions commonly used by the quantitative macroeconomic literature (see e.g. Uribe and Schmitt-Grohé (2017)). The second category includes Greek-specific features. The commonly used frictions include various types of adjustment costs, debt-elastic interest rates when the country borrows from abroad, imperfect competition, nominal rigidities, etc. The Greek-specific features include a relatively detailed public sector, problems of institutional quality and, since the beginning of the sovereign debt crisis in 2009, international financial assistance combined with fiscal austerity.

In what follows, we briefly introduce the building blocks of the model. 
Households There are three distinct types of households, called capital owners, workers and public employees. ${ }^{5}$ Capital owners own the private firms and banks and so receive their profits. They can also purchase government bonds and participate in the international financial market. ${ }^{6}$ Private workers work in private firms. Public employees work in state firms. Both workers and public employees may also keep deposits at private banks. All types of households consume a domestic and a foreign imported good, receive income from different types of work, hold currency and are engaged in rent-seeking activities (the latter are discussed below). The three types of households are modeled in Section 2.2.

Private Firms The domestic final good is produced by final good firms that act competitively using differentiated intermediate goods. The latter are produced by intermediate goods firms which act monopolistically à la Dixit-Stiglitz and face nominal rigidities à la Rotemberg. Intermediate goods firms choose labor, capital and imported goods and also make use of productivity-enhancing public goods/services that enter the private production function as an externality. They finance their capital accumulation by retained earnings and by loans from private banks. There are also capital good firms that produce the capital demanded by intermediate goods firms. Any profits generated by private firms are distributed to capital owners. Firms are modeled in Section 2.3.

Private Banks On the asset side, private banks make loans to private firms. On the side of liabilities, they receive deposits from savers and loans from the national central bank. To model the profit-maximizing behavior of private banks, and also account for the possibility that borrowing and lending takes place in equilibrium, we adopt the framework of Curdia and Woodford (2011). ${ }^{7}$ Within this framework, the difference between deposit and lending interest rate emerges as a result of heterogeneity in patience between savers (here, workers and public employees) and borrowers (here, firms or, equivalently their owners, capital owners) as well as of costly financial intermediation. Any profits generated by private banks are distributed to capital owners. Banks are modeled in Section 2.4.

State firms State firms use public employees, goods purchased from the private sector and public capital (the latter is augmented by public investment spending) to produce a public good that provides utility-enhancing services to households and productivity-enhancing services to firms, where the associated spending inputs as shares of GDP, as well as the fraction of public employees in population, will be set as in the data. State firms are in Section 2.5.

\footnotetext{
${ }^{5}$ Typically, some type of agent heterogeneity is necessary if we want to have savers and borrowers and different interest rates in equilbrium (see below for details).

${ }^{6}$ See e.g. Lansing (2015) for concentrated capital ownership of this type.

${ }^{7}$ The model of Gertler and Kiyotaki (2010) and Gertler and Karadi (2011) is another popular model in this literature. We do not believe the particular model of the banking sector is important to our results. We use the Curdia-Woodford model for its relative simplicity. Walsh (2017, chapter 11) reviews this literature.
} 
National Central Bank (NCB) in the Eurosystem (ES) On the side of assets, the NCB makes loans to private banks and may also hold government bonds. On the liabilities side, the monetary base consists of banknotes and cross-border TARGET2 liabilities (these are the two largest liability items in the Greek data; by contrast, reserves held by private banks at the Greek NCB are small in magnitude and so are assumed away). In other words, the NCB's spending is financed by printing new banknotes held by private agents and by issuing TARGET2 liabilities to other NCB's according to the rules of the ES. Any portfolio profits generated by the NCB are transferred to its own government in the form of a lump-sum dividend. The NCB is modeled in Section 2.6.2.

Treasury On the revenue side, the Treasury, or the government, taxes income and consumption, receives a dividend from its NCB and/or from the ECB and issues sovereign bonds. The latter can be purchased by domestic investors (private agents and the national central bank) and by foreign investors (where foreign investors can be both private and public like EU institutions and the ECB). On the expenditure side, the Treasury spends on wages of public employees, government investment, government purchases of goods from the private sector, as well as transfer payments to households. We assume that the government may partially default on its debt obligations to private holders of sovereign bonds which implies that public debt is not riskless and anticipation of this affects private portfolio choices. The Treasury is presented in Section 2.6.1.

Macroeconomic Policy Regime We assume that, during the years of the Greek sovereign debt crisis, monetary policy was shaped by the public and banking financing needs of the country. Specifically, we assume that, during these years, the ECB followed an accommodative policy towards Greece, in the sense that quantitative monetary policies, and in particular the issuance of TARGET2 liabilities to the ES, were adjusted so as to ensure that Greece's consolidated government budget constraint was satisfied in each period, while the tax-spending-public debt mix (including the official fiscal bailouts) is set as in the data. This is in Section 2.6.4.

Stationarity in a Small Open Economy As is known, we need an "imperfection" to get a stationary solution in a small-open economy model. Popular devices include a debt-elastic interest rate when agents borrow from abroad, or a transaction cost again when agents borrow from abroad, or an endogenous time preference rate (see e.g. Schmitt-Grohé and Uribe (2003)). Here, to bring the dynamics of the model closer to the data, we will assume both a debt-elastic country interest rate and transaction costs, although one is enough to guarantee stationarity. The country debt-elastic interest rate is in Section 2.8, while transaction costs associated with borrowing from private foreign markets are in Sections 2.2.1 and 2.6.1.

Institutions As said above, in most situations, poor institutions show up in illdefined property rights and the most common way of modeling the latter has been 
to assume that private and/or communal properties become "common pools". 8 Then, access to a common pool distorts individual incentives to work or save and this leads to resource misallocation and poor macroeconomic performance. Here, we will assume that, because of weak property rights, producers can appropriate only a fraction of their output, while the rest can be taken away by rent seekers, where the latter are assumed to be all types of households who compete with each other for a fraction of the contestable prize in a Tullock-type redistributive contest. Our measure of the degree of property rights will be set as in the data, while the rent-seeking technology is specified in Sections 2.2 and 2.3.2.

A Remark Modelling details will be provided as we present each building block of the above described model. Before we proceed, we wish to make a remark about unemployment. By assuming market-clearing in the labor market(s), any fall in output is obviously reflected in a fall in hours of work rather than in unemployed people. This is for simplicity. We have experimented with an extended version of our model that allows for both less hours of work and less employed people whenever output happens to fall. In particular, we have implemented this by replacing the supply of labor function with a wage rigidity rule as in e.g. Blanchard and Gali (2007), and where any decrease in the demand for labor on the part of firms is divided between a decrease in work hours and a decrease in the number of working people as in Ball and Romer (1990). Since the main results are not affected by this extension, we present the version of the model without unemployed people.

\subsection{Households}

There are three distinct types of households, called capital owners, workers and public employees. Capital owners are indexed by the subscript $k=1,2, \ldots, N^{k}$, workers by the subscript $w=1,2, \ldots N^{w}$, and public employees by the subscript $b=1,2, \ldots, N^{b}$. That is, the total population is $N=N^{k}+N^{w}+N^{b}$. Equivalently, in terms of population ratios, we define $n^{k} \equiv \frac{N^{k}}{N}, n^{w} \equiv \frac{N^{w}}{N}$ and $n^{b} \equiv \frac{N^{b}}{N}=1-n^{k}-n^{w}$. For simplicity, total population and its decomposition to the three groups is exogenous and kept constant over time; we also assume away occupational mobility from one group to another.

\subsubsection{Households as Capital Owners}

Capital owners own the firms and banks and receive their profits, purchase government bonds and can participate in the international asset market. Besides, like all other types of households, they receive income from work, hold currency and are engaged in rent-seeking activities.

\footnotetext{
${ }^{8}$ See e.g. Persson and Tabellini (2000, chapter 14), Drazen (2000, chapters 8 and 10), Acemoglu (2009, chapter 4) and Besley and Ghatak (2010) for common-pool problems, weak property rights and extraction.
} 
Each capital owner, $k=1,2, \ldots, N^{k}$, maximizes discounted lifetime utility:

$$
\sum_{t=0}^{\infty}\left(\beta_{k}\right)^{t} u\left(c_{k, t}, u_{k, t} h_{k, t} ; \bar{y}_{t}^{g}\right)
$$

where $c_{k, t}, u_{k, t}$ and $h_{k, t}$ denote respectively $k$ 's consumption, leisure time and endof-period currency (in real terms), ${ }^{9} \bar{y}_{t}^{g}$ denotes the per capita quantity of public goods/services provided and produced by the government, and $0<\beta_{k}<1$ is capital owners' time discount factor.

For our numerical solutions, we will use the utility function:

$$
u\left(c_{k, t}, u_{k, t}, h_{k, t} ; \bar{y}_{t}^{g}\right)=\mu_{1} \log c_{k, t}+\mu_{2} \log u_{k, t}+\mu_{3} \log h_{k, t}+\mu_{4} \log \bar{y}_{t}^{g}
$$

where $0<\mu_{1}, \mu_{2}, \mu_{3}, \mu_{4}<1$ are preference parameters with $\mu_{1}+\mu_{2}+\mu_{3}+\mu_{4}=1$.

Since there are two goods, home and foreign, we define the consumption index:

$$
c_{k, t}=\frac{\left(c_{k, t}^{h}\right)^{v}\left(c_{k, t}^{f}\right)^{1-v}}{v^{v}(1-v)^{1-v}}
$$

where $c_{k, t}^{h}$ and $c_{k, t}^{f}$ denote $k$ 's domestic and foreign consumption respectively and $0<v<1$ measures the weight given to the domestic good relative to the foreign good.

The time constraint of each $k$ in each period is:

$$
l_{k, t}+s_{k, t}+u_{k, t}=1
$$

where $l_{k, t}$ and $s_{k, t}$ are respectively $k$ 's effort time allocated to productive work and anti-social or rent seeking activities.

The within-period budget constraint of each $k$ written in real terms is:

$$
\begin{aligned}
\left(1+\tau_{t}^{c}\right) & \left(\frac{p_{t}^{h}}{p_{t}} c_{k, t}^{h}+\frac{p_{t}^{f}}{p_{t}} c_{k, t}^{f}\right)+b_{k, t}+\left(1+i_{t}^{*}\right) \frac{p_{t-1}^{*}}{p_{t}^{*}} \frac{e_{t} p_{t}^{*}}{p_{t}} f_{k, t-1} \\
+ & \frac{p_{t}^{h}}{p_{t}} \psi^{p}(.)+h_{k, t} \\
& \equiv\left(1-\tau_{t}^{y}\right) w_{t}^{k} l_{k, t}+\pi_{k, t}^{i}+\pi_{k, t}^{p} \\
+ & \left(1-\Theta_{t}\right)\left(1+i_{t}^{b}\right) \frac{p_{t-1}}{p_{t}} b_{k, t-1}+\frac{e_{t} p_{t}^{*}}{p_{t}} f_{k, t}+\frac{p_{t-1}}{p_{t}} h_{k, t-1}+\bar{g}_{t}^{t r} \\
+ & \left(\frac{\Gamma^{k}\left(s_{k, t}\right)^{\gamma}}{N^{k} \Gamma^{k}\left(s_{k, t}\right)^{\gamma}+N^{w} \Gamma^{w}\left(s_{w, t}\right)^{\gamma}+N^{b} \Gamma^{b}\left(s_{b, t}\right)^{\gamma}}\right)\left(1-P R_{t}\right) Y_{t}
\end{aligned}
$$

where $p_{t}^{h}$ is the price of the domestic good, $p_{t}^{f}$ is the price of the foreign good expressed in domestic currency, $p_{t}$ is the country's CPI specified below, $p_{t}^{*}$ is the CPI abroad, $e_{t}$ is the nominal exchange rate (an increase means a depreciation), $b_{k, t}$ is the real value of one-period government bonds purchased by each $k$ at $t$ and earning a nominal interest rate $i_{t+1}^{b}$ at $t+1,0 \leq \Theta_{t}<1$ is the actual default rate on

\footnotetext{
${ }^{9}$ We could instead use a cash-in-advance model. This is not important to our results.
} 
sovereign public debt (or the size of haircut), $f_{k, t}$ is the real value of one-period foreign debt denominated in foreign prices and acquired by each $k$ at $t$ on which $k$ pays the country-specific nominal interest rate $i_{t+1}^{*}$ at $t+1$ (if $f_{k, t}<0$, it denotes a foreign asset and $i_{t+1}^{*}$ is its nominal return at $\left.t+1\right),{ }^{10} w_{t}^{k}$ is the real wage rate paid to capital owners, $\pi_{k, t}^{i}$ is the dividend paid to each $k$ by private firms net of taxes, $\pi_{k, t}^{p}$ is the dividend paid to each $k$ by private banks net of taxes, $h_{k, t}$ is the real value of currency carried over from $t$ to $t+1, \psi^{p}($.$) is a transaction cost function associ-$ ated with the agent's participation in the foreign capital market (defined below), $\bar{g}^{t r}$ is a uniform transfer from the government and $0 \leq \tau_{t}^{c}, \tau_{t}^{y}<1$ are the tax rates on consumption and income.

The last term on the RHS of Eq. $3 b$ is the amount extracted by each $k$ from the common pool. Given weak property rights, we assume that total real output, defined as $Y_{t},{ }^{11}$ is a common pool or a contestable prize, so that only a fraction of it, $P R_{t} Y_{t}$, remains in the hands of its producers because the rest, $\left(1-P R_{t}\right) Y_{t}$, is taken away by rent seekers, where the rents extracted by each person depend on the anti-social activities employed by him/her relative to total anti-social activities. That is, $0<P R_{t} \leq 1$ is the degree of protection of property rights and the term $\left(\frac{\Gamma^{k}\left(s_{k, t}\right)^{\gamma}}{N^{k} \Gamma^{k}\left(s_{k, t}\right)^{\gamma}+N^{w} \Gamma^{w}\left(s_{w, t}\right)^{\gamma}+N^{b} \Gamma^{b}\left(s_{b, t}\right)^{\gamma}}\right)$ is the fraction of the common pool extracted by each $k$ in a Tullock (1980) type rent-seeking competition. Regarding the rentseeking technology, as in e.g. Dixit (2004, chapter 5) and Hillman (2009, chapter 2), the power coeffcient, $\gamma$, is between 0 and 1 and measures how quickly diminishing returns arise in anti-social activities, while the parameter $\Gamma^{k}$ measures the efficacy of $k$ 's aggresion. Both are measures of the technology of fighting. If $\Gamma^{k}$ increases and/or $\gamma$ decreases, agent $k$ has a stronger incentive to devote effort time to rent seeking. Note that this specification, specifically, the different values of $\Gamma^{k}, \Gamma^{w}$ and $\Gamma^{b}$, allows us to have asymmetries in equilibrium; namely, different types of rent seekers can choose different allocations and receive different wages even if they attack the same pie and share the same preferences. ${ }^{12}$

Regarding the per agent cost associated with participation in the foreign financial market, it is assumed to take the form:

$$
\psi^{p}(.) \equiv \frac{1}{N_{t}^{k}} \frac{\psi^{p}}{2}\left[\frac{\frac{e_{t} p_{t}^{*}}{p_{t}}\left(N_{t}^{k} f_{k, t}+F_{t}^{g}\right)}{\frac{p_{t}^{h}}{p_{t}} Y_{t}}-\bar{f}\right]^{2} Y_{t}
$$

where $\psi^{p} \geq 0$ is a transaction cost parameter associated with participation in foreign capital markets, $F_{t}^{g}$ denotes total public foreign debt (i.e. public debt issued by the domestic government and held by foreign private investors) denominated in

\footnotetext{
${ }^{10}$ This is denominated in foreign currency. That is, if $F_{k, t}$ is the nominal value for each agent $k$, the real value is $f_{k, t} \equiv \frac{F_{k, t}}{p_{t}^{*}}$.

${ }^{11}$ As we shall see below, $Y_{t} \equiv N^{i} \frac{p_{t}^{h}}{p_{t}} y_{i, t}^{h}$, where $N^{i}$ is the number of private firms and $y_{i, t}^{h}$ is the product of each of those firms.

${ }^{12}$ For simpler rent seeking technologies with identical agents, see e.g. Murphy et al. (1991), Hillman (2009, chapter 2), Esteban and Ray (2011), etc, while, quantitative DSGE models include Angelopoulos et al. (2009) and Christou et al. (2020).
} 
foreign currency, ${ }^{13} N_{t}^{k} f_{k, t}$ denotes total private foreign debt denominated in foreign currency, $Y_{t}$ is total real output and the parameter $\bar{f}$ is a threshold value of the country's foreign debt as share of GDP above which such costs arise. In other words, the cost is increasing in the country's total real foreign debt to total real GDP.

Each $k$ acts competitively choosing $\left\{c_{k, t}^{h}, c_{k, t}^{f}, c_{k, t}, l_{k, t}, s_{k, t}, b_{k, t}, f_{k, t}, h_{k, t}\right\}_{t=0}^{\infty}$ subject to the above. The first-order conditions are presented in the online Appendix A.1. It is worth pointing out that, in the Euler equation for government bonds, $b_{k, t}$, the private sector's beliefs about the default rate on sovereign debt obligations in the next period, denoted as $\Theta_{t+1}^{e}$, namely, the ex ante probability of sovereign default, affect private portfolio choices. Of course, these beliefs can be confirmed or not confirmed so, in general, actual default, $\Theta_{t}$, can differ from anticipated one, $\Theta_{t+1}^{e}$ (see Section 3.1 below for the measurement of $\Theta_{t}$ and $\Theta_{t+1}^{e}$ ).

\subsubsection{Households as Workers}

Workers are employed by private firms. Like all other households, they consume, work, hold currency and participate in rent-seeking activities. Workers may also save in the form of bank deposits. ${ }^{14}$

Each worker, $w=1,2, \ldots, N^{w}$, maximizes:

$$
\sum_{t=0}^{\infty} \beta^{t} u\left(c_{w, t}, u_{w, t}, h_{w, t} ; \bar{y}_{t}^{g}\right)
$$

where variables are defined as above in the capital owners' problem if we replace the subscript $k$ with the subscript $w$ and $0<\beta<1$ is workers' time discount factor. We will assume $0<\beta_{k}<\beta<1$, which will induce savers (here, workers and public employees) to have bank deposits and borrowers (here, firms) to take on debt in equilibrium. ${ }^{15}$

As above, we use the utility function:

$$
u\left(c_{w, t}, u_{w, t}, h_{w, t} ; \bar{y}_{t}^{g}\right)=\mu_{1} \log c_{w, t}+\mu_{2} \log u_{w, t}+\mu_{3} \log h_{w, t}+\mu_{4} \log \bar{y}_{t}^{g}
$$

and the consumption index:

$$
c_{w, t}=\frac{\left(c_{w, t}^{h}\right)^{v}\left(c_{w, t}^{f}\right)^{1-v}}{v^{v}(1-v)^{1-v}}
$$

Also as above, the maximization is subject to the time constraint:

$$
l_{w, t}+s_{w, t}+u_{w, t}=1
$$

\footnotetext{
${ }^{13}$ For more details, see the government budget constraint below.

${ }^{14}$ The assumption that workers and public employees do not participate in all asset markets is without loss of generality. We could assume that all households face transaction costs that make costly their participation in asset markets but workers and public employees face higher costs.

${ }^{15}$ See also e.g. Benigno et al. (2014), Korinek and Simsek (2016) and Philippopoulos et al. (2017b) for permanent differences in discount factors between savers and borrowers. Curdia and Woodford (2011) also assume differences in the degree of impatience among savers and borrowers although this difference does not remain fixed over time (this is not important to our results). Also, in Gertler and Kiyotaki (2010) and Gertler and Karadi (2011), bankers face a probability of exit, which effectively reduces their time discount factor as in the perpetual youth model.
} 
and the budget constraint:

$$
\begin{aligned}
\left(1+\tau_{t}^{c}\right) & \left(\frac{p_{t}^{h}}{p_{t}} c_{w, t}^{h}+\frac{p_{t}^{f}}{p_{t}} c_{w, t}^{f}\right)+j_{w, t}+h_{w, t} \\
& \equiv\left(1-\tau_{t}^{y}\right) w_{t}^{w} l_{w, t}+\left(1+i_{t}^{d}\right) \frac{p_{t-1}}{p_{t}} j_{w, t-1}+\frac{p_{t-1}}{p_{t}} h_{w, t-1}+\bar{g}_{t}^{t r} \\
& +\left(\frac{\Gamma^{w}\left(s_{w, t}\right)^{\gamma}}{N^{k} \Gamma^{k}\left(s_{k, t}\right)^{\gamma}+N^{w} \Gamma^{w}\left(s_{w, t}\right)^{\gamma}+N^{b} \Gamma^{b}\left(s_{b, t}\right)^{\gamma}}\right)\left(1-P R_{t}\right) Y_{t}
\end{aligned}
$$

where $w_{t}^{w}$ is the real wage rate of workers and $j_{w, t}$ is the real value of each $w$ 's bank deposits chosen at $t$ and paying a nominal interest rate $i_{t+1}^{d}$ at $t+1$. Notice that workers are assumed to have access to the same contestable prize as all other agents. They also receive the same transfer paid by the government to all other households.

Each $w$ acts competitively choosing $\left\{c_{w, t}^{h}, c_{w, t}^{f}, c_{w, t}, l_{w, t}, s_{w, t}, j_{w, t}, h_{w, t}\right\}_{t=0}^{\infty}$ subject to the above. The first-order conditions are in the online Appendix A.2.

\subsubsection{Households as Public Employees}

Public employees are employed by state firms. Like all other households, they consume, work, hold currency and are engaged in rent-seeking activities. Also, like workers, they may save in the form of bank deposits. Variables will be defined as above in the workers' problem if we replace the subscript $w$ with the subscript $b$.

Each public employee, $b=1,2, \ldots, N^{b}$, maximizes:

$$
\sum_{t=0}^{\infty} \beta^{t} u\left(c_{b, t}, u_{b, t}, h_{b, t} ; \bar{y}_{t}^{g}\right)
$$

As above, the ulility function and the consumption index are:

$$
\begin{gathered}
u\left(c_{b, t}, 1-l_{b, t}, h_{b, t} ; \bar{y}_{t}^{g}\right)=\mu_{1} \log c_{b, t}+\mu_{2} \log u_{b, t}+\mu_{3} \log h_{b, t}+\mu_{4} \log \bar{y}_{t}^{g} \\
c_{b, t}=\frac{\left(c_{b, t}^{h}\right)^{v}\left(c_{b, t}^{f}\right)^{1-v}}{v^{v}(1-v)^{1-v}}
\end{gathered}
$$

Also, as above, the maximization is subject to the time constraint:

$$
l_{b, t}+s_{b, t}+u_{b, t}=1
$$

and the budget constraint:

$$
\begin{aligned}
\left(1+\tau_{t}^{c}\right) & \left(\frac{p_{t}^{h}}{p_{t}} c_{b, t}^{h}+\frac{p_{t}^{f}}{p_{t}} c_{b, t}^{f}\right)+j_{b, t}+h_{b, t} \\
& \equiv\left(1-\tau_{t}^{y}\right) w_{t}^{g} l_{b, t}+\left(1+i_{t}^{d}\right) \frac{p_{t-1}}{p_{t}} j_{b, t-1}+\frac{p_{t-1}}{p_{t}} h_{b, t-1}+\bar{g}_{t}^{t r} \\
& +\left(\frac{\Gamma^{b}\left(s_{b, t}\right)^{\gamma}}{N^{k} \Gamma^{k}\left(s_{k, t}\right)^{\gamma}+N^{w} \Gamma^{w}\left(s_{w, t}\right)^{\gamma}+N^{b} \Gamma^{b}\left(s_{b, t}\right)^{\gamma}}\right)\left(1-P R_{t}\right) Y_{t}
\end{aligned}
$$

where $w_{t}^{g}$ is the real wage in the public sector while the rest of the variables are defined as in the worker's problem. 
Each $b$ acts competitively choosing $\left\{c_{b, t}^{h}, c_{b, t}^{f}, c_{b, t}, l_{b, t}, s_{b, t}, j_{b, t}, h_{b, t}\right\}_{t=0}^{\infty}$ subject to the above. ${ }^{16}$ The first-order conditions are in the online Appendix A.3.

\subsection{Private Firms and Production of Private Goods}

Private firms are owned by capital owners. Following most of the related literature, there are three types of goods produced by three associated types of firms. There is a single domestic final good produced by competitive final good firms. There are also differentiated intermediate goods used as inputs for the production of the final good. Each differentiated intermediate good is produced by an intermediate goods firm that acts as a monopolist in its own product market à la Dixit-Stiglitz facing Rotembergtype nominal fixities. Finally, competitive capital good firms produce capital used as an input in the production of intermediate goods. As in the literature, the essential role is played by intermediate goods firms.

\subsubsection{Final Good Firms}

There are $N^{h}$ final good firms indexed by subscript $h=1,2, \ldots, N^{h}$. For notational simplicity, we will set $N^{h}=N^{k}$, that is, the number of final good firms equals the number of their owners. Each final good firm produces an amount $y_{h, t}^{h}$ by using intermediate goods according to the standard Dixit-Stiglitz technology:

$$
y_{h, t}^{h}=\left[\sum_{i=1}^{N^{i}} \frac{1}{N^{i}}\left(y_{i, t}^{h}\right)^{\theta}\right]^{\frac{1}{\theta}}
$$

where $y_{i, t}^{h}$ denotes the quantity of intermediate good of variety $i=1,2, \ldots, N_{t}^{i}$ used by each final good firm $h$ and $0 \leq \theta \leq 1$ is a parameter measuring the degree of substitutability (when $\theta=1$, intermediate goods are perfect substitutes in the production of the final good and the intermediate goods sector is perfectly competitive).

Each final-good producer chooses $y_{i, t}^{h}$ to maximize real profits:

$$
y_{h, t}^{h}-\sum_{i=1}^{N^{i}} \frac{1}{N^{i}} \frac{p_{i, t}^{h}}{p_{t}^{h}} y_{i, t}^{h}
$$

where $p_{t}^{h}$ is the price of the final good and $p_{i, t}^{h}$ is the price of intermediate good $i$.

The firm maximizes its profit acting competitively subject to the above. The familiar first-order condition for inputs used is in the online Appendix A.4.

\subsubsection{Intermediate Goods Firms}

There are $N^{i}$ intermediate goods firms indexed by the subscript $i=1,2, \ldots, N^{i}$. Since they are owned and managed by capital owners, we again set $N^{i}=N^{k}$ for

\footnotetext{
${ }^{16}$ The choice of $l_{b, t}$ can be thought as a choice of work effort. Allowing for a fixed shift, or hours of work, in the public sector would not change our results to the extent that public employees can still choose the effort they make while at work.
} 
notational simplicity. These firms make investment and other factor decisions facing capital and Rotemberg-type price adjustment costs. New investment is financed by retained earnings and loans from private banks. ${ }^{17}$

The gross profit of each $i$, denoted as $\pi_{i, t}^{\text {gross }}$, is sales minus the wage bill minus the cost of imported goods minus adjustment costs associated with changes in capital and prices:

$$
\begin{gathered}
\pi_{i, t}^{g r o s s} \equiv P R_{t} \frac{p_{i, t}^{h}}{p_{t}} y_{i, t}^{h}-w_{t}^{w} l_{i, t}^{w}-w_{t}^{k} l_{i, t}^{k}-\frac{p_{t}^{f}}{p_{t}} m_{i, t}^{f} \\
-\frac{p_{t}^{h}}{p_{t}} \frac{\xi^{k}}{2}\left(\frac{k_{i, t}}{k_{i, t-1}}-1\right)^{2} k_{i, t-1}-\frac{p_{t}^{h}}{p_{t}} \frac{\xi^{p}}{2}\left(\frac{p_{i, t}^{h}}{p_{i, t-1}^{h}}-1\right)^{2} \bar{y}_{i, t}^{h}
\end{gathered}
$$

where $l_{i, t}^{w}$ is labor services provided by workers and used by firm $i, l_{i, t}^{k}$ is labor services provided by capital owners and used by $i, m_{i, t}^{f}$ is imported goods used by each $i, k_{i, t}$ is capital goods purchased from capital good producers by each $i$ in the current period and used in the next period (as we shall see below, the relative price of capital is 1$), \xi^{k}$ is a parameter measuring standard capital adjustment costs and $\xi^{p}$ is a parameter measuring Rotemberg-type price adjustment costs. ${ }^{18}$ Finally, as said above, firms can appropriate only a fraction, $0<P R_{t} \leq 1$, of their output because of insecure property rights.

This gross profit is used for retained earnings, the payment of corporate taxes to the government, dividends to shareholders and interest payments for loans received from private banks:

$$
\begin{aligned}
\pi_{i, t}^{\text {gross }} \equiv & R E_{i, t}+\tau_{t}^{\pi}\left(P R_{t} \frac{p_{i, t}^{h}}{p_{t}} y_{i, t}^{h}-w_{t}^{w} l_{i, t}^{w}-w_{t}^{k} l_{i, t}^{k}-\frac{p_{t}^{f}}{p_{t}} m_{i, t}^{f}\right)+ \\
& +\pi_{i, t}+i_{t}^{l} \frac{p_{t-1}}{p_{t}} L_{i, t-1}
\end{aligned}
$$

where $R E_{i, t}$ is retained earnings, $0 \leq \tau_{t}^{\pi}<1$ a profit tax rate, $\pi_{i, t}$ is net dividends paid to shareholders by firm $i$ and $L_{i, t-1}$ is the inherited bank loan on which the firm pays a nominal interest rate, $i_{t}^{l}$, at $t$.

Purchases of new capital, i.e. investment, are financed by retained earnings and new loans from private banks:

$$
\frac{p_{t}^{h}}{p_{t}}\left[k_{i, t}-(1-\delta) k_{i, t-1}\right] \equiv R E_{i, t}+\left(L_{i, t}-\frac{p_{t-1}}{p_{t}} L_{i, t-1}\right)
$$

\footnotetext{
${ }^{17}$ For simplicity, we assume that firms do not issue shares (purchased by capital owners) but simply distribute net profits to their owners (the capital owners). Allowing for issuance of shares leaves our results unchanged to the extent that we impose that the number of shares is constant (say at one) before solving the firm's optimization problem (for this typical case, see e.g. Miao (2014, chapter 14) and Uribe and Schmitt-Grohe (2017, chapter 4).

${ }^{18}$ Rotemberg-type costs associated with price changes are assumed to be proportional to average output, $\bar{y}_{i, t}^{h}$, which is taken as given by each $i$. This is not important but helps the smooth dynamics of the model.
} 
Combining the above constraints, the firm's net dividend, $\pi_{i, t}$, is:

$$
\begin{aligned}
\pi_{i, t} \equiv & \left(1-\tau_{t}^{\pi}\right)\left[P R_{t} \frac{p_{i, t}^{h}}{p_{t}} y_{i, t}^{h}-w_{t}^{w} l_{i, t}^{w}-w_{t}^{k} l_{i, t}^{k}-\frac{p_{t}^{f}}{p_{t}} m_{i, t}^{f}\right] \\
& -\frac{p_{t}^{h}}{p_{t}}\left[k_{i, t}-(1-\delta) k_{i, t-1}\right]-\frac{p_{t}^{h}}{p_{t}} \frac{\xi^{k}}{2}\left(\frac{k_{i, t}}{k_{i, t-1}}-1\right)^{2} k_{k, t-1} \\
& -\frac{p_{t}^{h}}{p_{t}} \frac{\xi^{p}}{2}\left(\frac{p_{i, t}^{h}}{p_{i, t-1}^{h}}-1\right)^{2} \bar{y}_{i, t}^{h}+ \\
& +\left(L_{i, t}-\left(1+i_{t}^{l}\right) \frac{p_{t-1}}{p_{t}} L_{i, t-1}\right)
\end{aligned}
$$

For the firm's production function, we adopt the form:

$$
y_{i, t}^{h}=A^{p}\left(\frac{N^{g} y_{g, t}^{g}}{N^{i}}\right)^{\sigma}\left[\left(\chi^{p}\left(k_{i, t-1}\right)^{o p}+\left(1-\chi^{p}\right)\left(m_{i, t}^{f}\right)^{o p}\right)^{\frac{\alpha}{o p}}\left(A^{w} l_{i, t}^{w}+A^{k} l_{i, t}^{k}\right)^{1-\alpha}\right]^{1-\sigma}
$$

where the parameter $0 \leq \chi^{p} \leq 1$ measures the intensity of capital, $k_{i, t-1}$, relative to goods imported from abroad, $m_{i, t}^{f}$, the parameter op $\geqslant 0$ measures the degree of substitutability between capital and imported goods, the coefficient $1-a$ is the share of labor inputs, the parameters $A^{w}$ and $A^{k}$ measure the relative productivity of workers and capital owners respectively, $A^{p}>0$ is TFP in the private sector and $0 \leq \sigma \leq 1$ is the contribution of public goods/services per firm to private production.

Firms are assumed to be subject to a borrowing constraint. ${ }^{19}$ Following most of the related literature (see e.g. Garin (2015), Guntner (2015), etc), we assume that firms can borrow up to a fraction of their capital:

$$
L_{i, t} \leq \rho^{l} \frac{p_{t}^{h}}{p_{t}} k_{i, t-1}
$$

where the parameter $\rho^{l} \geq 0$ measures the tightness of borrowing conditions.

Therefore, each firm $i$ maximizes the discounted sum of dividends distributed to its owners:

$$
\sum_{t=0}^{\infty}\left(\beta_{i, t}\right)^{t} \pi_{i, t}
$$

where, since firms are owned by capital owners, we will ex post postulate that the firm's discount factor, $\beta_{i, t}$, equals the capitall owners' marginal rate of substitution between consumption at $t$ and $t+1, \beta_{i, t} \equiv \frac{\beta_{k}\left(1+\tau_{t}^{c}\right) c_{k, t}}{\left(1+\tau_{t+1}^{c}\right) c_{k, t+1}} \cdot{ }^{20}$

The firm chooses $\left\{l_{i, t}^{w}, l_{i, t}^{k}, m_{i, t}^{f}, k_{i, t}, L_{i, t}\right\}_{t=0}^{\infty}{ }_{t+0}^{c}{ }^{c} c_{k, t+1}$ maximize its stream of dividends or net profits, as defined in Eqs. 14 and 17, subject to the production function in Eq. 15, the borrowing constraint in Eq. 16 and the inverse demand function for its product coming from the final good firm's problem. Details and the firm's first-order conditions are in the online Appendix A.5.

\footnotetext{
${ }^{19}$ We could assume different types of constraints as in e.g. Uribe and Schmitt-Grohé (2017) and Sims and $\mathrm{Wu}$ (2020). We do not believe this is important to our results.

${ }^{20}$ See also e.g. Uribe and Schmitt-Grohe (2017, pp. 110-111).
} 


\subsubsection{Capital Good Firms}

There are $N^{c}$ capital good firms indexed by the subscript $c=1,2, \ldots, N^{c}$. Since they are owned by capital owners, we again set $N^{c}=N^{k}$ for notational simplicity. Working similarly to e.g. Guntner (2015), Uribe and Schmitt-Grohe (2017, pp. 79 and 110), and many others, we assume that capital good producers aquire the depreciated capital stock, choose investment activity and sell the latter to intermediate goods firms. Here, this problem is modeled in the simplest possible way by assuming away adjustment costs, so that, in each period, each firm $c$ maximizes its profit given by:

$$
\pi_{c, t} \equiv Q_{t} x_{c, t}-x_{c, t}
$$

where $x_{c, t}$ is the amount of investment produced and $Q_{t}$ is the relative price of capital also known as Tobin's $q$. Here, without capital adjustment costs, the first-order condition is simply $Q_{t}=1$ as assumed above. Also, the profit is zero in equilibrium.

\subsection{Private Banks}

There are $N^{p}$ private banks indexed by the subscript $p=1,2, \ldots, N^{p}$. Since they are owned and managed by capital owners, we again set $N^{p}=N^{k}$ for notational simplicity. In addition to their standard role, which is the provision of intermediation between lenders and borrowers by converting bank deposits into loans to firms, we also allow private banks to receive loans from the NCB. In other words, on the side of liabilities, private banks receive deposits from households and take loans from the $\mathrm{NCB}$, while, on the asset side, they make loans to private firms. As said above, we do not include reserves held by banks at the NCB; this is simply because they are small in the Greek data (see Section 3.2 below for data). Any profits made by banks are distributed to the capital owners.

The budget constraint of each $p$ that connects changes in its assets and liabilities is (written in real and per capita terms):

$$
\begin{aligned}
L_{p, t}+ & \pi_{p, t}+\left(1+i_{t}^{d}\right) \frac{p_{t-1}}{p_{t}} j_{p, t-1} \\
+ & \frac{p_{t}^{h}}{p_{t}} \Xi\left(L_{p, t}, z_{p, t}\right)+\left(1+i_{t}^{z}\right) \frac{p_{t-1}}{p_{t}} z_{p, t-1} \\
& \equiv\left(1+i_{t}^{l}\right) \frac{p_{t-1}}{p_{t}} L_{p, t-1}+j_{p, t}+z_{p, t}
\end{aligned}
$$

where $L_{p, t}$ is loans given to firms on which banks receive the nominal interest rate $i_{t+1}^{l}$ one period later, $\pi_{p, t}$ is bank profits distributed to bank owners in a lump-sum fashion, $j_{p, t}$ is bank deposits on which banks pay the nominal interest rate $i_{t+1}^{d}$ one period later, $z_{p, t}$ is loans from the NCB to the private bank on which the latter pays the nominal policy interest rate $i_{t+1}^{z}$ one period later and $\Xi\left(L_{p, t}, z_{p, t}\right)$ is real operational costs faced by banks that are assumed to be increasing in the volumes of loans given to firms and loans taken from the NCB. In what folows, we will use the 
functional form $\Xi\left(L_{p, t}, z_{p, t}\right)=\frac{\xi^{l}}{2}\left(L_{p, t}\right)^{2}+\frac{\xi^{z}}{2}\left(z_{p, t}\right)^{2}$, which can give well-defined demand and supply functions. ${ }^{21}$

Loans from the NCB to private banks are assumed to be subject to a borrowing constraint. Similarly to the firm's problem above, we assume that each private bank can borrow up to a fraction of its assets:

$$
z_{p, t} \leq \rho^{z} L_{p, t}
$$

where the parameter $\rho^{z} \geq 0$ measures the tightness of borrowing conditions.

The bank's profit maximization problem subject to the above is solved as in e.g. Curdia and Woodford (2011) and Corsetti et al. (2013). Modeling details and firstorder conditions for the supply of loans to firms, $L_{p, t}$, and the demand for credit from the NCB, $z_{p, t}$, are in the online Appendix A.6.

\subsection{State Firms and Production of Public Goods/Services}

We now model the way in which state enterprises produce the publicly provided good/service. There are $N^{g}$ state firms indexed by the subscript $g=1,2, \ldots, N^{g}$ producing a single public good/service. For notational simplicity, we will set $N^{g}=$ $N^{b}$, that is, the number of state firms equals the number of public employees.

The cost of each state firm $g$ for producing the public good is in real terms:

$$
w_{t}^{g} l_{g, t}+\frac{p_{t}^{h}}{p_{t}}\left(g_{g, t}^{g}+g_{g, t}^{i}\right)+\frac{p_{t}^{f}}{p_{t}} m_{g, t}^{g}
$$

where $l_{g, t}$ is labor services used by each state firm $g, g_{g, t}^{g}$ is goods purchased from the private sector by each $g, g_{g, t}^{i}$ is investment made by each $g$, and $m_{g, t}^{g}$ is imported goods used by each $g$.

The production function of each state firm $g$ is assumed to be similar to that in the private sector:

$$
y_{g, t}^{g}=A^{g}\left(\chi^{g}\left(k_{g, t-1}^{g}\right)^{o g}+\left(1-\chi^{g}\right)\left(m_{g, t}^{g}\right)^{o g}\right)^{\frac{\theta_{1}}{o g}}\left(l_{g, t}\right)^{\theta_{2}}\left(g_{g, t}^{g}\right)^{1-\theta_{1}-\theta_{2}}
$$

where $0 \leq \chi^{g} \leq 1$ measures the intensity of public capital, $k_{g, t-1}^{g}$, relative to goods imported from abroad, $m_{g, t}^{g}$, the parameter $o g \geqslant 0$ measures the degree of substitutability between public capital and imported goods, the coefficients $0<\theta_{1}, \theta_{2}$, $1-\theta_{1}-\theta_{2}<1$ measure the shares of the associated factors in production and $A^{g}>0$ is TFP in the public sector.

The stock of each state firm's capital evolves over time as:

$$
k_{g, t}^{g}=\left(1-\delta^{g}\right) k_{g, t-1}^{g}+g_{g, t}^{i}
$$

where $0<\delta^{g}<1$ is the depreciation rate of public capital.

To specify the level of output produced by each state firm, $y_{g, t}^{g}$, and hence the total amount of public goods/services provided to the society, we obviously have to specify the amounts of inputs, $l_{g, t}, g_{g, t}^{g}, m_{g, t}^{g}$ and $k_{g, t}^{g}$ (or equivalently $g_{g, t}^{i}$ ). Except from

\footnotetext{
${ }^{21}$ In Curdia and Woodford (2011), banks intermediate between borrowers and lenders and the associated intermediation cost falls with bank reserves held at the central bank.
} 
work hours or effort which is determined by public employees (see their problem above), we will consider the case in which the values of these inputs are as implied by the data, meaning that the total number of public employees as a share of population, as well as the associated government expenditures (on public investment, public wages, goods purchased from the private sector and imported goods), as shares of GDP, are set as in the data. Specifically, we define $g_{g, t}^{i}=\frac{s_{t}^{i} n^{k} y_{i, t}^{h}}{n^{b}}, g_{g, t}^{g}=\frac{s_{t}^{g} n^{k} y_{i, t}^{h}}{n^{b}}$, $m_{g, t}^{g}=\frac{p_{t}^{h}}{p_{t}^{f}} \frac{s_{t}^{m} n^{k} y_{i, t}^{h}}{n^{b}}$ and $w_{t}^{g}=\frac{s_{t}^{w} \frac{p_{t}^{h}}{p_{t}} n^{k} y_{i, t}^{h}}{n^{b} l_{b, t}}$, where $n^{b} \equiv \frac{N^{b}}{N}$ is the fraction of public employees in population and $s_{t}^{i}, s_{t}^{g}, s_{t}^{m}$ and $s_{t}^{w}$ are respectively the GDP shares of government expenditures on investment, goods purchased from the private sector, imported goods and public wages; these values will be set according to the data (see Section 3.2 and the online Appendix B for data).

\subsection{Fiscal and Monetary Policy}

This section models separately the Treasury and the Greek National Central Bank participating in the Eurosystem (ES). This can help us to understand the menu of fiscal and monetary policy instruments available to policymakers and how these instruments interact with each other. Before we proceed formally, we need to put our work in the context of the literature on the nexus between fiscal, public financing and quantitative monetary policies.

As is well known, the massive expansion in central bank balance sheets since the onset of the 2007-8 global financial crisis has forced a re-examination of Wallace's (1981) neutrality property according to which the central bank's balance sheet, or quantitative, policies (which have to do with the total size of the central bank's balance sheet and the mix of assets and liabilities that the central bank holds) do not have any real effects. However, as a response to these massive quantitative policies, the literature has added various financial frictions to the benchmark framework that result in asset pricing wedges and thereby departures from Wallace's property. Examples of such frictions include transaction costs, borrowing constraints, market segmentation, limited market participation, moral hazard, etc (see e.g. Walsh (2017, chapter 11), Reis (2017), Benigno and Nistico (2017) and Bassetto and Sargent (2020) for reviews). ${ }^{22}$ Once we allow for such frictions, quantitative monetary policies can have fiscal implications and can also affect the real economic activity. ${ }^{23}$

On top of this, as e.g. Sinn and Wollmershauser (2012), Sinn (2014) and Reis (2017) have pointed out, in a currency union like the ES, there can be extra, direct routes through which quantitative monetary policies can alleviate fiscal burdens and relax national constraints, even in the absence of financial frictions like the above. The currency union's central bank, like the ECB in the ES, can play a redistributive

\footnotetext{
${ }^{22}$ The Curdia and Woodford (2011) model, also adopted here (see Section 2.4), is one out of several models allowing for such a departure from Wallace's benchmark case. See Walsh (2017, chapter 11).

${ }^{23}$ The literature has focused on three important questions: first, the role of the central bank as a fiscal actor and, specifically, what happens to the central bank when it attempts to alleviate fiscal burdens; second, the associated direct or indirect benefits for the government; third, the impact on the real economic activity.
} 
role by relaxing the fiscal and resource constraints of some regions and by tightening those of others. Specifically, Reis (2017, section 10) has argued that several of the ECB's policies (like the SMP, the provision of ELA and the way ECB's dividends are re-allocated to member-countries of the EZ) can belong to this category allowing for redistribution of real resources among governments and nations within the ES. A parallel literature (Sinn and Wollmershauser (2012) and Sinn (2014)) has argued that the issuance of TARGET2 balances can work in the same redistributive way (TARGET2 balances, which are particularly large in the case of Greece, are discussed in some detail below).

In our paper, we will adopt a formal criterion that helps us to judge whether a quantitative, or balance-sheet, monetary policy can play a direct allocative role: it can, if, once market-clearing conditions have been taken into account, this policy instrument remains as an item in the economy's resource constraint, namely, its balance of payments. According to this criterion, as we shall see below, purchases of government bonds by the ES beyond those purchased by the NCB, dividends given by the ES to the national government again beyond those given by its own NCB, as well as the issuance of TARGET2 liabililities by the NCB as part of its monetary base, can, at least in principle, play an allocative role and practically work like the official fiscal bailouts replacing private capital inflows from abroad (as argued by Sinn and Wollmershauser (2012) and Sinn (2014)).

We now present separately the Treasury and the National Central Bank.

\subsubsection{The Treasury (Fiscal Authorities)}

The Treasury, or the fiscal branch of government, uses revenues from taxes on labor income, capital income and consumption, the issuance of government bonds and a direct receipt/dividend from the central bank to finance its various spending activities. This is standard; we will only differ in who can hold Greek public debt so as to embed the official bail out.

Public Debt and its Holders Let us define the real and per capita public debt at the end of period $t$ as $d_{t}$. We assume that it can be held by four different types of creditors: domestic private agents, the $\mathrm{NCB},{ }^{24}$ foreign private agents, and foreign public

\footnotetext{
${ }^{24}$ In the theoretical model, for comparison to the literature, we allow for government bond purchases by the NCB or the ECB (actually, in the ES, most of government bond purchases are carried out by the NCBs rather than by the ECB itself; see e.g. Sinn (2014, chapter 8)). On the other hand, in the numerical solutions below, we will set the fraction of Greek public debt owned by the NCB or the ECB at zero. This is for several reasons. For instance, these government bond purchases take place in the secondary market only which means that, strictly speaking, any beneficial effects (like reductions in sovereign spreads) on public finances are indirect (see e.g. Gibson et al. (2015) for Greece). Also, being under its economic adjustment program that ended in 2018, Greece was not part of the official large-scale asset purchase program of the ECB that started in early 2015. However, it should be acknowledged that, in practice, things are not so clear. The ECB has supported Greek govenment bonds in several other ways. For instance, as Sinn (2014) has pointed out, support to Greek private banks by the ECB has also been support to the Greek government since private banks can use the loans given by the ECB to purchase bonds which are in turn used as collaterals for new loans from the ECB. All this is on top of TARGET2 balances which are introduced below.
} 
institutions, where the latter include EU institutions like the ESM and other euro states, which are labeled as "EU". ${ }^{25}$ In the pre-crisis period (2001-2008), the public debt was mainly held by private (domestic and foreign) agents/banks, while during the years of the debt crisis most of the Greek public debt has changed hands and is now being held by the "EU" as part of Greece's various bailout programs (see Section 3.2 and the online Appendix B for data).

In particular, $d_{t}$ is decomposed to:

$$
d_{t} \equiv b_{t}^{d}+b_{t}^{n c b}+\frac{e_{t} p_{t}^{*}}{p_{t}} f_{t}^{g}+\frac{e_{t} p_{t}^{*}}{p_{t}} f_{t}^{e u}
$$

where, expressing them as fractions of total debt, we define: ${ }^{26}$

$$
\begin{gathered}
b_{t}^{d} \equiv \lambda_{t}^{d} d_{t} \\
b_{t}^{n c b} \equiv \lambda_{t}^{n c b} d_{t} \\
\frac{e_{t} p_{t}^{*}}{p_{t}} f_{t}^{g} \equiv \lambda_{t}^{g} d_{t} \\
\frac{e_{t} p_{t}^{*}}{p_{t}} f_{t}^{e u} \equiv \lambda_{t}^{e u} d_{t}
\end{gathered}
$$

where $0 \leq \lambda_{t}^{d}, \lambda_{t}^{n c b}, \lambda_{t}^{g}, \lambda_{t}^{e u} \leq 1$ are the fractions of Greek public debt held respectively by domestic private agents, the NCB, foreign private agents and the EU, where $\lambda_{t}^{d}+\lambda_{t}^{n c b}+\lambda_{t}^{g}+\lambda_{t}^{e u}=1 .^{27}$ If the policy and rest-of-the-world variables, $\lambda_{t}^{n c b}$, $\lambda_{t}^{g}$ and $\lambda_{t}^{e u}$, are exogenously given (they will be set as in the data), then residually $\lambda_{t}^{d}=\left(1-\lambda_{t}^{n c b}-\lambda_{t}^{g}-\lambda_{t}^{e u}\right) .^{28}$

\footnotetext{
${ }^{25}$ The three official inter-governmental fiscal bailouts to Greece since 2010 amount to around 290 billion euros. This has been provided by the EFSF, the ESM as well as by other euro states. These are loans to countries in need, like Greece, after these countries sign a memorandum of understanding to implement an economic adjustment programme (see e.g. Sinn (2014, chapter 8)). In the case of Greece, most of this money has been used for public debt servicing payments which means the repayment of maturing government debt, the service of interest payments on existing government debt and various forms of bond exchanges that helped private banks and creditors to offload their holdings of Greek government bonds. As a result, today, around 70\% of Greek public debt is owned by these European public institutions (see the data in the online Appendix B). Since these holdings are recorded as public debt (see e.g. the Greek Public Debt Management Agency and the Greek Ministry of Finance), we label this as Greek public debt held by the EU.

${ }^{26}$ That is, if $F_{t}^{g}$ denotes the nominal value of total public foreign debt expressed in foreign currency, $f_{t}^{g} \equiv \frac{F_{t}^{g}}{p_{t}^{*} N}$ is its per capita and real value

${ }^{27}$ As said, in our baseline solutions, we set $\lambda_{t}^{n c b} \equiv 0$.

${ }^{28} \mathrm{We}$ have also experimented with the case in which the bonds bought by the EU have more than one period maturity so as to capture the longer maturity of these loans in reality. We report that adding multiperiod safe loans by the EU (and the associated interest rates) does not change our main results. Perhaps this is because optimizing private agents are rational and forward-looking.
} 
Budget Constraint of the Treasury Using this notation, the flow budget constraint of the government written in per capita and real terms is:

$$
\begin{aligned}
\bar{g}_{t}^{t r}+n^{b} & {\left[w_{t}^{g} l_{g, t}^{g}+\frac{p_{t}^{h}}{p_{t}}\left(g_{g, t}^{g}+g_{g, t}^{i}\right)+\frac{p_{t}^{f}}{p_{t}} m_{g, t}^{g}\right] } \\
& +\left(1-\Theta_{t}\right)\left(1+i_{t}^{b}\right) \frac{p_{t-1}}{p_{t}} \lambda_{t-1}^{d} d_{t-1} \\
& +\left(1-\Theta_{t}\right)\left(1+i_{t}^{b}\right) \frac{p_{t-1}^{*}}{p_{t}^{*}} \frac{e_{t} p_{t}^{*}}{p_{t}} \frac{p_{t-1}}{e_{t-1} p_{t-1}^{*}} \lambda_{t-1}^{g} d_{t-1} \\
& +\left(1+i^{*}\right) \frac{p_{t-1}}{p_{t}} \lambda_{t-1}^{n c b} d_{t-1}+\left(1+i^{*}\right) \frac{p_{t-1}^{*}}{p_{t}^{*}} \frac{e_{t} p_{t}^{*}}{p_{t}} \frac{p_{t-1}}{e_{t-1} p_{t-1}^{*}} \lambda_{t-1}^{e u} d_{t-1} \\
& +\frac{p_{t}^{h}}{p_{t}} \psi^{g}(.) \equiv d_{t}+\frac{T_{t}}{N}+r c b_{t}^{g}
\end{aligned}
$$

where $\bar{g}_{t}^{t r}$ is the lump-sum transfer to each household, $n^{b}\left[w_{t}^{g} l_{g, t}^{g}+\frac{p_{t}^{h}}{p_{t}}\left(g_{g, t}^{g}+g_{g, t}^{i}\right)\right.$ $\left.+\frac{p_{t}^{f}}{p_{t}} m_{g, t}^{g}\right]$ is the cost of state firms, $\psi^{g}($.$) is a transaction cost function associ-$ ated with the government's participation in the foreign capital market (defined right below), $\frac{T_{t}}{N}$ denotes tax revenues (defined right below) and $r c b_{t}^{g}$ is a direct transfer/dividend from the central bank to the Treasury. ${ }^{29}$ The rest of the terms capture interest payments on public debt where notice that the interest rates vary depending on the identity of the creditor. For instance, we assume that when the government borrows from the EU or the ES, it pays the constant world interest rate, $i^{*}$, only, while, when the government borrows from the (domestic and foreign) market, is pays the market interest rate, $i_{t}^{b}$. As said above, we allow the government to partially default (at a fraction $0 \leq \Theta_{t}<1$ ) on its debt obligations to the private sector (domestic and foreign); this is consistent with the data (the haircut in Greek public debt did not apply to public institutions).

As in Eq. 4 above, we assume that the cost associated with participation in the foreign financial market takes the form:

$$
\psi^{g}(.) \equiv \frac{\psi^{g}}{2}\left[\frac{\frac{e_{t} p_{t}^{*}}{p_{t}}\left(n^{k} f_{k, t}+\lambda_{t}^{g} d_{t}\right)}{\frac{p_{t}^{h}}{p_{t}} n^{k} y_{i, t}^{h}}-\bar{f}\right]^{2} n^{k} y_{i, t}^{h}
$$

where $\psi^{g} \geq 0$ is a transaction cost parameter associated with public borrowing from foreign markets.

\footnotetext{
${ }^{29}$ See e.g. Walsh (2017, chapter 4), Reis (2013, 2017), Benigno and Nistico (2017) and Bassetto and Sargent (2020). In the ES, similarly to the purchase of government bonds, there are rules applying to the amount of dividends distributed by the ECB to each national fiscal authority. However, see e.g. Reis (2017, section 10) for details, and perhaps exceptions, in the case of Greece.
} 
Total tax revenues in real and per capita terms are:

$$
\begin{array}{r}
\frac{T_{t}}{N} \equiv \tau_{t}^{c}\left[n^{k}\left(\frac{p_{t}^{h}}{p_{t}} c_{k, t}^{h}+\frac{p_{t}^{f}}{p_{t}} c_{k, t}^{f}\right)+n^{w}\left(\frac{p_{t}^{h}}{p_{t}} c_{w, t}^{h}+\frac{p_{t}^{f}}{p_{t}} c_{w, t}^{f}\right)+\right. \\
\left.+n^{b}\left(\frac{p_{t}^{h}}{p_{t}} c_{b, t}^{h}+\frac{p_{t}^{f}}{p_{t}} c_{b, t}^{f}\right)\right]+\tau_{t}^{y} n^{k} w_{t}^{k} l_{k, t}+\tau_{t}^{y} n_{t}^{w, e} n^{w} w_{t}^{w} l_{w, t}+ \\
+\tau_{t}^{y} n^{b} w_{t}^{g} l_{b, t}+\tau_{t}^{\pi} n^{k}\left[P R_{t} \frac{p_{t}^{h}}{p_{t}} y_{i, t}^{h}-w_{t}^{w} \frac{n_{t}^{w, e} n^{w}}{n^{k}} l_{w, t}-w_{t}^{k} l_{k, t}-\frac{p_{t}^{f}}{p_{t}} m_{i, t}^{f}\right]
\end{array}
$$

One of the policy variables must follow residually to close the Treasury's budget constraint in Eq. 25; this will be defined below after we present the budget constraint of the NCB.

\subsubsection{The National Central Bank (NCB) in the Eurosystem (ES)}

Before we introduce the Greek NCB, we need to clarify how the balance sheet of a NCB participating in the ES is related to the consolidated balance sheet of the ES.

The ES and its NCBs The consolidated balance sheet and the budget constraint of the ES are not different from those of a standardized central bank. ${ }^{30}$ In other words, as is typically the case with central banks, the asset side of the balance sheet of the consolidated ES consists mainly of foreign currency, loans to credit institutions ${ }^{31}$ and securities/bonds. ${ }^{32}$ The liability side, again typically, consists mainly of banknotes in circulation (held by the non-bank public), reserves which are also called current accounts (held by private banks at the central bank) and government deposits.

However, the consolidated balance sheet of the ES shows assets and liabilities of the ES's NCBs and the ECB itself vis-à-vis third parties only. In other words, it does not include credits and debits among NCBs and the ECB, known as Intra-Eurosystem claims and liabilities and recorded respectively as TARGET2 assets and TARGET2 liabilities in the financial statements of the individual NCBs and the ECB. As first pointed out by Sinn and Wollmershauser (2012) and Sinn (2014), and further studied by Whelan (2014, 2017), Perotti (2020) and many others, these are net bilaterals positions vis-a-vis the ES, which means that the NCB of a member country transferring money abroad records a TARGET2 liability to the rest of the ES, while the NCB of a member country receiving the money from abroad records a TARGET2 asset. These TARGET2 balances cancel each other out at aggregate ES level (this is by construction) and therefore do not appear in the consolidated balance sheet of the ES as

\footnotetext{
${ }^{30}$ See e.g. "Annual consolidated balance sheet of the ES" and "User guide on the ES consolidated weekly financial statement" (available at the site of the ECB). For the conduct of monetary policy in the ES, see e.g. "The monetary policy of the ECB" (ECB, , chapter 4).

${ }^{31}$ This includes the main refinancing operations (MROs), longer-term refinancing operations (LTROs), marginal lending facilities, etc. It also inludes emergency liquidity assistance (ELA) to private banks with severe liquidity problems. See e.g. Gibson et al. (2019).

${ }^{32}$ This includes the covered bond purchase program (CBPP), the securities markets program (SMP), the asset purchase program (APP) since 2015, etc.
} 
described above. ${ }^{33}$ However, they do appear in the balance sheets of individual NCBs and the ECB, in the sense that they enter as an extra item of liabilities for a country with Intra-Eurosystem liabilities like Greece (see e.g. Whelan, 2014, Table 2) or as an extra item of assets for a country with Intra-Eurosystem claims like Germany (see e.g. Whelan, 2014, Table 3). In other words, for a country like Greece, TARGET2 liabilities have become a part of the monetary base created by its NCB in accordance with the rules of the ES.

Looking at the data, as is well recognized, there was an explosion of TARGET2 balances after 2008. For the ES as a whole, TARGET2 balances were very small prior to the crisis but have increased substantially since then; they were 186 billion euros in May 2008, 416 billions in July 2011, 1.09 trillion in August 2012 and 1.24 trillion in September 2017 (see Whelan (2017, Figure 1)). In the case of Greece, TARGET2 liabilities were, for instance, 105 billion euros in 2011 which translates into $105 / 168=62 \%$ of the total liabilities of the Greek NCB or $105 / 207=51 \%$ of GDP, and 94 billion euros in 2015, which translates into $94 / 163=58 \%$ of the total liabilities of the Greek NCB or 94/177 $=53 \%$ of GDP. ${ }^{34}$ Actually, as is reported in some detail in the data appendix (see online Appendix B), in the case of Greece, TARGET2 liabilities have been by far the largest item of liabilities, and hence of the monetary base, of the Greek NCB in every year between 2008 and 2017. ${ }^{35}$

Budget Constraint of the NCB Given the above facts, on the side of assets of the Greek NCB, we will include loans to private banks and government securities, while, on the side of liabilities, we will include banknotes in circulation and TARGET2 liabilities. These are the largest asset and liability items in the financial statemenst of the Greek NCB (see online Appendix B for data). ${ }^{36}$ Then, the budget constraint of the NCB linking changes in assets and liabilities is (written in real and per capita terms):

$$
n^{k} z_{p, t}+\lambda_{t}^{n c b} d_{t}+r c b_{t}^{g} \equiv
$$

\footnotetext{
${ }^{33}$ See e.g. Whelan $(2014,2017)$ and Perotti $(2020)$ for the mechanics of the TARGET2 system and how assets and liabilities of both private banks and NCBs change in response to various changes like moving money from a bank account in country A to a bank account in country B. As Sinn (2014, p. 187) says, "the outflow of money from Greece goes hand-in-hand with ... the inflow of money into Germany, ... in turn, leads to additional liquidity that German banks do not need and which they therefore choose to lend to the Bundesbank with the effect that the money is removed from the economy".

${ }^{34}$ As the data show (e.g. Whelan $\left.(2014,2017)\right)$, the same happened in other periphery countries of the EZ. For instance, in Ireland, TARGET2 liabilities peaked at around 90\% of GDP in 2010.

${ }^{35}$ Before we move on, it is worth recalling that, since the publication of the seminal paper by Sinn and Wollmershauser (2012), there has been a heated debate at both academic and policy circles over the role of these assets and liabilities. Opinions have ranged from TARGET2 being an innocent and mechanical protocol of the ES to being a hidden bailout of the periphery EZ countries in trouble (for the latter see Sinn (2014)). Today, to the best of our understanding, there is a kind of consensus, in the sense that the enormous magnitude of TARGET2 balances during the years of the debt crisis: (a) is closely related to fears of default and a euro break up (b) is closely related to loans to private banks and the ECB's balance sheet policies in general (c) facilated a capital flight from the periphery to the core (d) is not clearly timed to current account deficits in the periphery (see e.g. Whelan (2014) and Perotti (2020) for such a consensus). ${ }^{36}$ We do not include reserves held by private banks at the Greek NCB simply because they are small in magnitude in the data. This is different from the ES level where most of the increase in the monetary base of the ES has been in the form of reserves (see "Annual consolidated balance sheet of the ES" available at the ECB's site).
} 


$$
\begin{gathered}
\equiv\left(h_{t}^{n}-\frac{p_{t-1}}{p_{t}} h_{t-1}^{n}\right)+\left(T A R G_{t}-\frac{p_{t-1}}{p_{t}} T A R G_{t-1}\right)+ \\
+n^{k}\left(1+i_{t}^{z}\right) \frac{p_{t-1}}{p_{t}} z_{p, t-1}+\left(1+i_{t}^{*}\right) \frac{p_{t-1}}{p_{t}} \lambda_{t-1}^{n c b} d_{t-1}
\end{gathered}
$$

where $n^{k} z_{p, t}$ is the end-of period loans to private banks, $\lambda_{t}^{n c b} d_{t} \equiv b_{t}^{n c b}$ is the end-of-period government bonds purchased by the NCB (however, for the reasons explained above, we will set $\lambda_{t}^{n c b} \equiv 0$ in our baseline solutions), $r c b_{t}^{g}$ is the direct transfer/dividend from the NCB to its government (as said above, this is the NCB's balance-sheet earnings rebated to the Treasury), $h_{t}^{n}$ denotes the end-of-period stock of banknotes in circulation and $T A R G_{t}$ denotes the end-of-period stock of TARGET2 liabilities (for notational simplicity, which is also close to the data, we assume that the refinancing rate on TARGET2 balances is zero). In other words, in our model, $h_{t}^{n}+T A R G_{t} \equiv M B_{t}$ is the monetary base of the Greek NCB within the ES (these variables are written in real and per capita values).

In equilibrium, $h_{t}^{n}=n^{k} h_{k, t}+n^{w} h_{w, t}+n^{b} h_{b, t}$ at each $t$. In this case, TARGET2 liabilities are the difference between $M B_{t}$ and $n^{k} h_{k, t}+n^{w} h_{w, t}+n^{b} h_{b, t}$. In other words, to the extent that the monetary base of the NCB exceeds the amount of currency held by the public for liquidity services, ${ }^{37}$ or, loosely speaking, to the extent that the funds made available by the NCB are not only used to hold a larger stock of money balances, the country has a TARGET2 liability to the rest of the ES. ${ }^{38}$

We should make two further points here regarding TARGET2 liabilities. First, they are possible because, in a currency union (CU), the money market clears at a $\mathrm{CU}$ level rather than at local/national level. Second, the way in which these cross-country liabilities affect the real economy, and how they can be used, will become clear below when we present the country's balance of payments (as said above, this is our formal criterion to judge if a balance-sheet monetary policy item affects national resources).

One of the monetary policy variables must adjust residually to close the budget constraint in Eq. 28; this will be defined below jointly with the fiscal policy variable that closes the Treasury's budget constraint in Eq. 25.

\subsubsection{Budget Constraint of the Consolidated Public Sector}

To the extent that the transfer/dividend from the NCB to its government, $r c b_{t}^{g}$, is free and can be treated as an endogenous variable, we can combine the budget constraint of the Treasury in Eq. 25 and the budget constraint of the NCB in Eq. 28 into a single constraint, the budget identity of the consolidated public sector (see e.g. Reis (2017) and Benigno and Nistico (2017) for details). That is, by also using the marketclearing condition $h_{t}^{n}=n^{k} h_{k, t}+n^{w} h_{w, t}+n^{b} h_{b, t}$, we get (written in real and per capita terms):

$$
\bar{g}_{t}^{t r}+\left(1+i_{t}^{*}\right) \frac{p_{t-1}}{p_{t}} \lambda_{t-1}^{d} d_{t-1}
$$

\footnotetext{
${ }^{37}$ Or, equivalently, since assets are equal to liabilities by definition, to the extent that the claims of the $\mathrm{NCB}$ on its private sector exceed the amount of currency held for liquidity services.

${ }^{38} \mathrm{We}$ are grateful to Hans-Werner Sinn for comments on this issue. Any errors are ours.
} 


$$
\begin{aligned}
& +\left(1-\Theta_{t}\right)\left(1+i_{t}^{b}\right) \frac{p_{t-1}^{*}}{p_{t}^{*}} \frac{e_{t} p_{t}^{*}}{p_{t}} \frac{p_{t-1}}{e_{t-1} p_{t-1}^{*}} \lambda_{t-1}^{g} d_{t-1} \\
& +\left(1+i^{*}\right) \frac{p_{t-1}^{*}}{p_{t}^{*}} \frac{e_{t} p_{t}^{*}}{p_{t}} \frac{p_{t-1}}{e_{t-1} p_{t-1}^{*}} \lambda_{t-1}^{e u} d_{t-1} \\
& +n^{b}\left[w_{t}^{g} l_{g, t}^{g}+\frac{p_{t}^{h}}{p_{t}}\left(g_{g, t}^{g}+g_{g, t}^{i}\right)+\frac{p_{t}^{f}}{p_{t}} m_{g, t}^{g}\right] \\
& +\frac{p_{t}^{h}}{p_{t}} \frac{\psi^{g}}{2}\left[\frac{\frac{e_{t} p_{t}^{*}}{p_{t}}\left(n^{k} f_{k, t}+\lambda_{t}^{g} d_{t}\right)}{\frac{p_{t}^{h}}{p_{t}} n^{k} y_{i, t}^{h}}-\bar{f}\right]^{2} n^{k} y_{i, t}^{h}=\left(\lambda_{t}^{d}+\lambda_{t}^{g}+\lambda_{t}^{e u}\right) d_{t}+\frac{T_{t}}{N} \\
& +n^{k} h_{k, t}+n^{w} h_{w, t}+n^{b} h_{b, t}-\frac{p_{t-1}}{p_{t}}\left(n^{k} h_{k, t-1}+n^{w} h_{w, t-1}+n^{b} h_{b, t-1}\right) \\
& -n^{k}\left(z_{p, t}-\left(1+i_{t}^{z}\right) \frac{p_{t-1}}{p_{t}} z_{p, t-1}\right)+\left(T A R G_{t}-\frac{p_{t-1}}{p_{t}} T A R G_{t-1}\right)
\end{aligned}
$$

where all variables have been defined above.

Inspection of the above constraint confirms some standard properties, but also reveals some distinct features of the ES. Regarding standard properties, the NCB's purchase of bonds issued by its own government, $\lambda_{t}^{n c b} d_{t}$, as well as the provision of transfers/dividends to its own government, $r c b_{t}^{g}$, do not appear in the consolidated government budget constraint. This happens simply because when the NCB transfers resources to its own government, or vice versa, one type of liability replaces another (see e.g. Reis (2017)). As a consequence, the NCB can only generate revenue for its government through the real value of seigniorage, $\left(\frac{H_{t}^{n}-H_{t-1}^{n}}{p_{t}} \equiv h_{t}^{n}-\frac{p_{t-1}}{p_{t}} h_{t-1}^{n}\right)$, whose size is an empirical matter. This is standard. On the other hand, the same constraint reveals how, in a currency union, a single central bank like the ECB, that faces different fiscal authorities, can redistribute resources and thereby alleviate the fiscal burden of member-countries in need (see Reis (2017, section 10)). In particular, as the above constraint reveals, this can be done via purchases of government bonds beyond those purchased by the NCB (see the term $\lambda_{t}^{e u} d_{t}$ which, as said, can, in principle at least, include ECB's holdings) and by the permission to issue TARGET2 liabilities to the extent that this issue is beyond the amount of currency held by the public for liquidity services. As we shall see, the very same terms will also appear in the balance of payments presented below. Finally, it is worth adding here that had we allowed for direct transfers/dividends by the ECB beyond those provided by the NCB, these transfers/dividends would also remain in the budget constraint of the consolidated public sector (as well as, in the balance of payments below) and hence could play a redistributive allocative role similar to that played by $\lambda_{t}^{e u} d_{t}$ and TARGET2 liabilities.

As in Eqs. 25 and 28 above, one policy variable must adjust residually to close (29); this is defined right below.

\subsubsection{Fiscal-Monetary Policy Regime}

By policy regime, we typically mean a choice of which policy variables are set by the policy authorities and which have to follow endogenously/residually to accommodate the policy decisions made. 
Inspection of the budget constraints of the Treasury and the NCB, in Eqs. 25 and 28 respectively, reveal the various options available to fiscal and monetary authorities or, equivalently, the possible policy regimes. In other words, once one allows for a more realistic menu of monetary policy instruments as we have done here (in particular, assets and liabilities of the NCB and the associated policy interest rates), there is a wide range of policy regimes even in a small open economy within a currency union or with fixed exchange rates.

Here, to capture the fiscal austerity mix adopted by the Greek governments, the shutting out of the country from international private capital markets, as well as the official fiscal bailouts and the plethora of accommodative quantitative monetary policies followed by the ECB towards Greece during the sovereign debt crisis years, we will set all tax rates, all types of government spending as shares of GDP, the public debt-to-GDP ratio jointly with its decomposition to various holders (including the foreign public institutions, labeled as EU in our model), as they have been in the actual data over the crisis years, and then assume that the transfer/dividend from the NCB to the government, $r c b_{t}^{g}$, is residually determined by the NCB's budget constraint in Eq. 28, which implies, as said above, that the budget constraint of the NCB and the budget constraint of the Treasury can be merged into the single consolidated budget constraint in Eq. 29, and, in turn, assume that the latter is satisfied by adjustments in the monetary base. Actually, to the extent that the monetary base consists of banknotes in circulation and TARGET2 liabilities, $M B_{t} \equiv h_{t}^{n}+T A R G_{t}$, where the banknotes in circulation are determined by the currency demanded by the public for liquidity-providing services, $h_{t}^{n}=n^{k} h_{k, t}+n^{w} h_{w, t}+n^{b} h_{b, t}$, endogeneity of the change in the monetary base practically means endogeneity of the cross-border liquidity term, $\left(T A R G_{t}-\frac{P_{t-1}}{P_{t}} T A R G_{t-1}\right) \cdot{ }^{39}$ In other words, we assume that the ECB has been following an accommodative policy towards Greece, in the sense that it has increased its monetary base and specifically the issuance of TARGET2 liabilities so as to accommodate the rest of policies as well as the macroeconomic developments occurring at the same time. At least at regional/national level, this is a regime of fiscal dominance meaning active fiscal policy and passive monetary policy (see e.g. Walsh (2017, chapter 4$)){ }^{40}$

\footnotetext{
${ }^{39}$ We could alternatively treat the end-of-period public debt as an endogenous variable with the change in TARGET2 liabilities following a feedback policy rule reacting to the beginning-of-period public debt. To the extent that the feedback policy coefficient is calibrated appropriately, the results do not change. However, since during most of the 2010s, the Greek government did not participate in the bond market, we prefer to set the debt as in the data and allow TARGET2 to adjust.

${ }^{40}$ As Reis (2019) points out, fiscal dominance at the EZ level has been avoided. On the other hand, monetary accommodation (via e.g. TARGET2 balances, purchase of national government bonds, sharing of ECB's dividends, provision of ELA, etc) has worked like fiscal dominance in those member-countries hit by the crisis.
} 


\subsection{Balance of Payments}

If we add up the budget constraints of all agents, we get the country's balance of payments (written in real and per capita terms):

$$
\begin{aligned}
\frac{p_{t}^{f}}{p_{t}}\left(n^{k} c_{k, t}^{f}\right. & \left.+n^{w} c_{w, t}^{f}+n^{b} c_{b, t}^{f}+n^{k} m_{i, t}^{f}+n^{b} m_{g, t}^{g}\right)-\frac{p_{t}^{h}}{p_{t}} c_{t}^{f *} \\
& +\left(1+i_{t}^{*}\right) \frac{p_{t-1}^{*}}{p_{t}^{*}} \frac{e_{t} p_{t}^{*}}{p_{t}} n^{k} f_{k, t-1} \\
& +\left(1-\Theta_{t}\right)\left(1+i_{t}^{b}\right) \frac{p_{t-1}^{*}}{p_{t}^{*}} \frac{e_{t} p_{t}^{*}}{p_{t}} \frac{p_{t-1}}{e_{t-1} p_{t-1}^{*}} \lambda_{t-1}^{g} d_{t-1} \\
& +\left(1+i^{*}\right) \frac{p_{t-1}^{*}}{p_{t}^{*}} \frac{e_{t} p_{t}^{*}}{p_{t}} \frac{p_{t-1}}{e_{t-1} p_{t-1}^{*}} \lambda_{t-1}^{e u} d_{t-1} \\
& +\frac{p_{t}^{h}}{p_{t}} \frac{\psi^{p}}{2}\left[\frac{\frac{e_{t} p_{t}^{*}}{p_{t}}\left(n^{k} f_{k, t}+\lambda_{t}^{g} d_{t}\right)}{\frac{p_{t}^{h}}{p_{t}} n^{k} y_{i, t}^{h}}-\bar{f}\right]^{2} n^{k} y_{i, t}^{h} \\
& +\frac{p_{t}^{h}}{p_{t}} \frac{\psi^{g}}{2}\left[\frac{\frac{e_{t} p_{t}^{*}}{p_{t}}\left(n^{k} f_{k, t}+\lambda_{t}^{g} d_{t}\right)}{\frac{p_{t}^{h}}{p_{t}} n^{k} y_{i, t}^{h}}-\bar{f}\right]^{2} n^{k} y_{i, t}^{h} \\
= & \frac{e_{t} p_{t}^{*}}{p_{t}} n^{k} f_{k, t}+\lambda_{t}^{g} d_{t}+\lambda_{t}^{e u} d_{t}+\left(T A R G_{t}-\frac{p_{t-1}}{p_{t}} T A R G_{t-1}\right)
\end{aligned}
$$

Inspection of the balance of payments reveals the cross-country redistributive role that the ECB can play at least in principle. This can be done by purchases of government bonds beyond those purchased by the NCB (see the term $\lambda_{t}^{e u} d_{t}$ which, as said above, can include ECB's holdings) and by allowing the NCB to issue excess liquidity in the form of TARGET2 liabilities to the rest of the ES (see the term $T A R G_{t}-\frac{p_{t-1}}{p_{t}} T A R G_{t-1}$, which, also as said above, becomes possible when the monetary base of the NCB exceeds the amount of currency held by the public for liquidity services). ${ }^{41}$ As is revealed by Eq. 30, these items can be used to finance imported goods, to repay foreign debt or to finance investments abroad.

A final clarification of the role of TARGET2: As pointed out by Sinn (2014, p. 180), our term $\left(T A R G_{t}-\frac{p_{t-1}}{p_{t}} T A R G_{t-1}\right)$ is the increase in "the amount of central bank credit that has been issued in excess of liquidity needs for transactions within the NCB's national jurisdiction". Had the economy been closed, or had we have a small open economy with a national currency, this term could not be present in the balance of payments; there could not be any use of extra self-created money in those cases. Here, it becomes possible thanks to participation in a currency union which means that the money market clears at currency union level, rather than at

\footnotetext{
${ }^{41}$ The same can happen, as said above, via direct transfers/dividends provided by the ECB beyond those provided by the country's NCB.
} 
national level within each jurisdiction, and that the currency issued (euro) works like an "international" currency at least within the EZ. ${ }^{42}$

\subsection{Country's Interest Rate}

Following most of the literature on small open economies (e.g. Schmitt-Grohé and Uribe (2003) and Uribe and Schmitt-Grohé (2017)), we assume that the interest rate at which private agents borrow from abroad, $i_{t}^{*}$, is public debt-elastic. In particular, we use the functional form:

$$
i_{t}^{*}=i^{*}+\psi^{*}\left(\exp \left(\frac{d_{t}}{\frac{p_{t}^{h}}{p_{t}} n^{k} y_{i, t}^{h}}-\bar{d}\right)-1\right)
$$

where $\psi^{*}$ is an interest-rate premium parameter and the parameter $\bar{d} \geq 0$ is a threshold value for the public debt-to-GDP ratio above which country premia emerge (for details and references, see Philippopoulos et al. (2017a)).

\subsection{Solution Steps and Methodology}

Market-clearing conditions and the macroeconomic system are respectively presented in Appendices A.8 and A.9 in the online Appendix. The system consists of 51 equations in 51 variables. This is given the paths of the exogenously set variables (see Appendix A.9 for a detailed list of endogenous and exogenous variables), whose values will be set as in the data.

In the next sections, we will parameterize the model, present the data used and in turn solve the system numerically. In particular, our quantitative analysis will consist of the following steps. First, after presenting parameter values and Greek data, we will get a stationary solution using data of the year 2008. As we shall see, this solution can match reasonably well the main features of the data before the eruption of the crisis and can thus serve as a departure point in what follows. This is in Section 3. In turn, departing from the 2008 solution, we will feed the model with the time-series of the exogenous variables as they have been in the data over 20082019. This will allow us to provide a quantitative assessment of the main drivers of the Greek depression between 2008 and 2016. In these solutions, along the transition of the economy to its new stationary equilibrium, we will assume that after 2019 (this is the last year that data for all exogenous variables are available) the model's exogenous variables remain as in 2019. But, we will also experiment with

\footnotetext{
${ }^{42}$ To make the point clearer, consider a miniature version of our model without financial intermediaries, a government or foreign assets. The budget constraints of the private sector and the NCB are respectively $c_{t}+\Delta h_{t}=y_{t}+\Delta z_{t}$ and $\Delta z_{t}=\Delta M B_{t}=\Delta h_{t}+\Delta T A R G_{t}$, where $h_{t}$ is currency held by the private agent, $z_{t}$ is a loan from the NCB (assume a zero interest rate), $M B_{t}$ denotes the monetary base, $\Delta x_{t} \equiv x_{t}-x_{t-1}$ and the rest are obvious and are as in the paper above. Then, adding them up, the economy's resource constraint or its balance of payments is $c_{t}=y_{t}+\Delta T A R G_{t}$. We are grateful to Hans-Werner Sinn for this model specification. Note that if the currency is national, so that the money market clears at national level, $h_{t}=z_{t}$ and hence $T A R G_{t}=0$ at any $t$.
} 
various counter-factual scenarios since 2008 that could have possibly made the economic downturn milder or worse. We will assume that all this is common knowledge so that we solve under perfect foresight ${ }^{43}$ using a Newton-type non-linear method implemented in DYNARE.

\section{Parameter Values, Data and Solution for 2008}

To make quantitative predictions, we solve the model numerically. In Section 3.1, we will present parameter values and introduce the data used for the specification of the exogenous variables. Section 3.2 will then present the stationary solution of the model when we use data for the year 2008 (this was the last year before the sovereign debt crisis started in Greece).

\subsection{Parameterization, Data and Exogenous Policy Variables}

Regarding structural parameters for technology and preferences, for most of them, we will use commonly employed values, while the rest will be calibrated on the basis of Greek data. Parameter values are listed in Table 1. We report at the outset that our main results are robust to changes in these baseline parameter values at least within reasonable ranges.

Starting with preference parameters, the time discount factors of savers and borrowers, $\beta$ and $\beta^{k}$, are set at 0.99 and 0.98 repectively so as to give a lending interest rate above the saving interest rate. The weights given to private consumption, leisure and real money holdings, $\mu_{1}, \mu_{2}$ and $\mu_{3}$ in households' utility function, are set respectively at $0.40,0.55$ and 0.03 , while the remaining, 0.02 , goes to utilityenhancing public goods/services; these values produce work hours, etc, within usual ranges. The degree of preference of home goods over foreign goods, $v$, is set at the neutral value of 0.5 ; this value also contributes to delivering reasonable ratios of home to foreign goods in households' consumption spending.

Continuing with technology parameters, in the production function of private goods, the exponent of labor, $1-\alpha$, is set at 0.6 , while, the rest, $a=0.4$, is the exponent of the CES term that includes capital and imported goods. In the same production function, the contribution of productivity-enhancing public goods/services to private production, $\sigma$, is set at 0.1 . The work productivity parameters of capital owners and workers in the private good production function, $A^{k}$ and $A^{w}$, are set at 3 and 2 respectively; this difference produces a skilled wage premium within usual ranges. In the private firm's production function, the parameter measuring the intensity of capital vis-a-vis imported goods, $\chi^{p}$, as well as the parameter measuring the substitutability between capital and imported goods, op, are both set at 0.5 ; the same value of 0.5 is used for $\chi^{g}$ and $o g$ in the state firm's production function. Also in the state firms' production function, the Cobb-Douglas exponents of public capital and public

\footnotetext{
${ }^{43}$ We have also solved the model assuming that exogenous variables follow, for example, a random walk process and that private agents' next period expected values are equal to their current values. We report that the main results are not affected.
} 
Table 1 Baseline parameterization

\begin{tabular}{|c|c|c|}
\hline Parameter & Description & Value \\
\hline$v$ & home goods bias in consumption & 0.5 \\
\hline$\mu_{1}$ & weight of consumption in utility & 0.4 \\
\hline$\mu_{2}$ & weight of leisure in utility & 0.55 \\
\hline$\mu_{3}$ & weight of money balances in utility & 0.03 \\
\hline$\beta$ & savers' time discount factor & 0.99 \\
\hline$\beta_{k}$ & borrowers' time discount factor & 0.98 \\
\hline$\delta$ & depreciation rate of private capital & 0.05 \\
\hline$\delta^{g}$ & depreciation rate of public capital & 0.05 \\
\hline$\psi^{p}$ & transaction cost in foreign capital market (private) & 0.5 \\
\hline$\psi^{g}$ & transaction cost in foreign capital market (public) & 0.5 \\
\hline$A^{p}$ & TFP in private sector's production function & 1 \\
\hline$A^{g}$ & TFP in public sector's production function & 1 \\
\hline$A^{k}$ & capital owners' labour productivity & 3 \\
\hline$A^{w}$ & workers' labour productivity & 2 \\
\hline $1-\alpha$ & share of labor in private production & 0.6 \\
\hline$\sigma$ & contribution of public output to private production & 0.1 \\
\hline$\theta_{1}$ & share of capital and imported goods in public production & 0.3045 \\
\hline$\theta_{2}$ & share of labor in public production & 0.6 \\
\hline$\chi^{p}$ & intensity of private capital relative to imported goods (private) & 0.5 \\
\hline$o p$ & substitutability between capital and imported goods (private) & 0.5 \\
\hline$x^{g}$ & intensity of public capital relative to imported goods (public) & 0.5 \\
\hline$o g$ & substitutability between capital and imported goods (public) & 0.5 \\
\hline$\xi^{k}$ & capital adjustment cost parameter & 0.3 \\
\hline$\xi^{l}$ & transaction cost associated with bank loans to firms & 0.3 \\
\hline$\xi^{z}$ & transaction cost associated with $\mathrm{NCB}$ loans to banks & 0.3 \\
\hline$\gamma$ & measure of diminishing returns in anti-social activities & 0.5 \\
\hline$\psi^{*}$ & country's interest-rate premium parameter & 0.05 \\
\hline $\bar{d}$ & threshold value of public debt to ouput & 1.1 \\
\hline$\Gamma^{k}$ & efficiency of capital owners' anti-social activity & 1 \\
\hline$\Gamma^{w}$ & efficiency of workers' anti-social activity & 0.7 \\
\hline$\Gamma^{b}$ & efficiency of public employees' anti-social activity & 1.3 \\
\hline$\Omega$ & constant in the function of exports & 0.5 \\
\hline$\vartheta$ & Cobb-Douglas exponent in the function of exports & 2 \\
\hline $\bar{f}$ & threshold value of external debt to output & 0.8 \\
\hline$i^{*}$ & constant term of world interest rate & 0.01 \\
\hline$\theta$ & substitutability between intermediate goods & 0.75 \\
\hline$\xi^{p}$ & price adjustment cost parameter (Rotemberg) & 3 \\
\hline$\rho^{l}$ & fraction in firms' borrowing constraint & 0.5 \\
\hline$\rho^{z}$ & fraction in banks' borrowing constraint & 0.5 \\
\hline$n^{k}$ & share of capital owners in population & 0.2 \\
\hline$n^{w}$ & share of workers in population & 0.6 \\
\hline$n^{b}$ & share of public employees in population (data) & 0.2 \\
\hline
\end{tabular}


employment, $\theta_{1}$ and $\theta_{2}$, are set respectively at 0.3045 and 0.6 , which correspond to payments for public investment and public wages, expressed as shares of total public payments to all inputs used in the production of public goods, as they are in the data; in turn, the Cobb-Douglas exponent of goods purchased from the private sector, $1-\theta_{1}-\theta_{2}$, follows residually. Both private and public capital depreciation rates, $\delta$ and $\delta^{g}$, are set at 0.05 . Similarly, both TFP parameters (in the private and in the public sector production functions) are normalized at 1 (note that public sector efficiency, and why it may differ from private sector efficiency, is crucial but is not an issue in this paper). In the baseline simulations, the Dixit-Stiglitz parameter capturing imperfect competition in product markets, $\theta$, is set at 0.75 , which produces a profit ratio around $10 \%$ in the case without structural reforms. Then, the same parameter will be assumed to increase gradually up to 0.8 in the case of structural reforms (see e.g. Eggertsson et al. (2014) for evidence in the core and periphery of the eurozone). In the rent-seeking technology, the power coefficient is set at 0.5 , which is common across all types of agents, while the effectiveness parameters of public employees, entrepreneurs and workers, $\Gamma^{b}, \Gamma^{k}$ and $\Gamma^{w}$, are set respectively at $1.3,1$ and 0.7 to reflect their relative political power in rent extraction.

The transaction cost parameters associated with capital changes in the firm's problem, private bank loans to firms and NCB loans to private banks, $\xi^{k}, \xi^{l}$ and $\xi^{z}$, are all set at 0.3 . The Rotemberg-type parameter associated with price changes in the firm's problem, $\xi^{p}$, is set at 3 . The two transaction cost parameters associated with private and public participation in the foreign capital market, $\psi^{p}$ and $\psi^{g}$, are set at 0.5 . The risk premium parameter in the debt-elastic interest rate rule, $\psi^{*}$, is set at 0.05 ; this belongs to usual ranges and also produces a foreign debt to GDP ratio as in the data when the crisis erupted. The fixed world interest rate, $i^{*}$, is set at $1 \%$. The two parameters in the function of exports, $\Omega$ and $\vartheta$, are set at 0.5 and 2 respectively; these values contribute to producing a trade deficit close to the data. The threshold values of public debt and foreign debt as shares of GDP, above which problems start, are set at 1.1 and 0.8 respectively which are values close to those in Reinhart and Rogoff (2009). The parameters in the two inequality borrowing constraints, $\rho^{l}$ and $\rho^{z}$, are set at 0.5 . The population fractions of public employees, $n^{b}$, and self-employed or capital owners, $n^{k}$, are set at 0.2 and 0.2 respectively as in the data, so that the fraction of workers, $n^{w}$, follows residually at 0.6 .

It remains to specify the actual and expected sovereign default rates, $\Theta_{t}$ and $\Theta_{t+1}^{e}$. As is known, there is a rich literature on the specification of default rates ranging from being a strategic variable to an endogenous variable determined by the fiscal limit or to an exogenously set variable consistent with the data. ${ }^{44}$ Here, to keep things simple, we follow the last approach. In particular, following the applied literature on risk management (see e.g. Hull (2015, chapter 19)), we assume that the probability of default in the next period, $\Theta_{t+1}^{e}$, equals the expected value of next period's spread of the 10-year Greek government bond yield versus that of Germany's divided by

\footnotetext{
${ }^{44}$ See e.g. the discussion and review in Corsetti et al. (2013).
} 
one minus the recovery rate in case of default. Using data on yields and assuming a recovery rate of say $50 \%$, which is on average what happens in actual haircuts (see e.g. Corsetti et al. (2013)), we get a time series of $\Theta_{t+1}^{e}$ with which we feed the model either as it is (assuming perfect foresight) or lagged once (assuming rational expectations to the extent that this variable follows a random walk). The simple formula used and the resulting numbers are presented in Appendix B of the online Appendix. On the other hand, actual or ex post default, $\Theta_{t}$, happened in 2012 and applied to private holders of Greek government bonds only. To capture this, in 2012, we multiply the fractions of the beginning-of-period public debt held by private (domestic and foreign) agents, $\lambda_{t-1}^{d} d_{t-1}$ and $\lambda_{t-1}^{g} d_{t-1}$, by $\left(1-\Theta_{t}\right)$, where $\Theta_{t}=0.48$ in 2012 and zero otherwise. We report that results are robust to changes in these values within reasonable ranges.

Finally, to solve the model, we also need time-series for the exogenous variables, like policy instruments, institutional quality, etc (as said above, a detailed list of the exogenous variables is in Appendix A.9). To save on space here, the time series of these exogenous variables, driving the transition dynamics, are presented in the data appendix (see Appendix B in the online Appendix). Here, we just wish to point out that these data also provide empirical support to several key assumptions of our model and shed light to some relatively unnoticed facts of the Greek sovereign debt crisis, especially those related to financial assistance from the EU/ECB and deterioration of institutional quality.

\subsection{Solution for the Pre-Crisis Year 2008}

Using the parameter values listed in Table 1 and data of the year 2008, the stationary solution of the model is reported in Table $2 \mathrm{a}$ and $\mathrm{b}$ (we report some key variables only). In this solution, variables do not change (so it can be thought as the "trend" of the Greek economy before the global financial crisis) and all exogenous variables have been set as in the data of the year 2008. The solution is in line with data averages over 2000-2008 and can thus provide a reasonable departure for the changes that have been taking place since 2009 and are studied in the next sections. In particular, the solution does a relatively good job at mimicking the position of the country in the international capital market, as well as the consumption-investment behavior of the private sector during the pre-crisis years.

\section{What Happened Between 2008 and 2019}

In this section, departing from the 2008 solution, we feed the model with the paths of the exogenous variables (e.g. policy variables, the index of property rights, etc) as explained above. In doing so, we assume that after 2019 the values of these variables remain unchanged as in 2019 which is the last value available in the data as this paper is written. In what follows, we will report both aggregate and distributional implications. 
Table 2 Solution for the year 2008

(a) Main variables in the solution for the year 2008

$\begin{array}{llll}\text { Variable } & \text { Description } & \text { Model solution } & \text { Data } \\ c / y & \text { Consumption to ouput } & 85.9 \% & 67.4 \% \\ \text { inv } / y & \text { Investment to output } & 19 \% & 23.8 \% \\ f / y & \text { Foreign debt to output } & 82.1 \% & 76 \%\end{array}$

(b) Other variables in the solution for the year 2008

$\begin{array}{llr}\text { Variable } & \text { Descritpion } & \text { Value } \\ c_{k} & \text { consumption of capital owner } & 0.309 \\ c_{w} & \text { consumption of private worker } & 0.160 \\ c_{b} & \text { consumption of public employee } & 0.253 \\ l_{k} & \text { work hours of capital owner } & 0.011 \\ l_{w} & \text { work hours of private worker } & 0.201 \\ l_{b} & \text { work hours of public employee } & 0.176 \\ T T & \text { terms of trade } & 0.309 \\ y & \text { per capita real output } & 0.243 \\ s_{k} & \text { capitalist's effort time allocated } & 0.085 \\ & \text { to anti-social activities } & 0.093 \\ s_{w} & \text { worker's effort time allocated to anti- } & 0.126 \\ s_{b} & \text { social activities } & \text { public employee's effort time allocated } \\ & \text { to anti-social activities } & \end{array}$

\subsection{Aggregate Effects}

Our baseline simulation for GDP, as well as its actual path in the data, are illustrated in Fig. 1, where the numbers indicate the percentage change in output relative to the 2008 solution. As can be seen, our model solution can mimic relatively well the actual behaviour of GDP over the crisis years, especially its cumulative change. For example, between 2008 and 2016, the total output loss generated by the model is $22.1 \%$ (namely, $100-77.9=22.1$ ), while it was $26.2 \%$ (namely, $100-73.8=26.2$ ) in the actual data. Given this, we feel that the model is empirically plausible and can allow us to draw some useful policy implications.

In Fig. 2, we decompose the simulated output loss into its main drivers. As the graph reveals, about $12 \%$ of the loss is due to the economic ajustment package adopted (where the latter includes fiscal austerity, structural reforms and the various forms of international financial assistance). Another 10\% (specifically, $87.9-77.9$ ) is due to the deterioration of institutional quality since 2008 . The role of the latter is striking. 


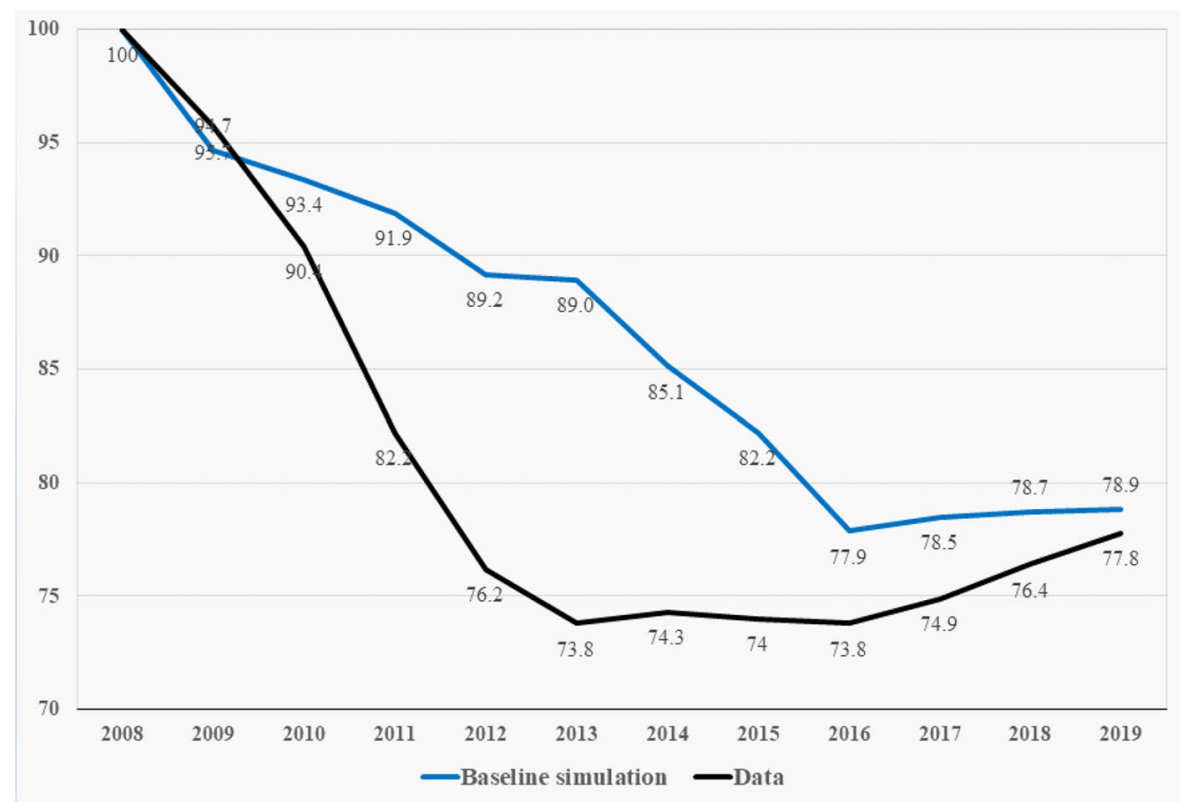

Fig. 1 Output loss and the data

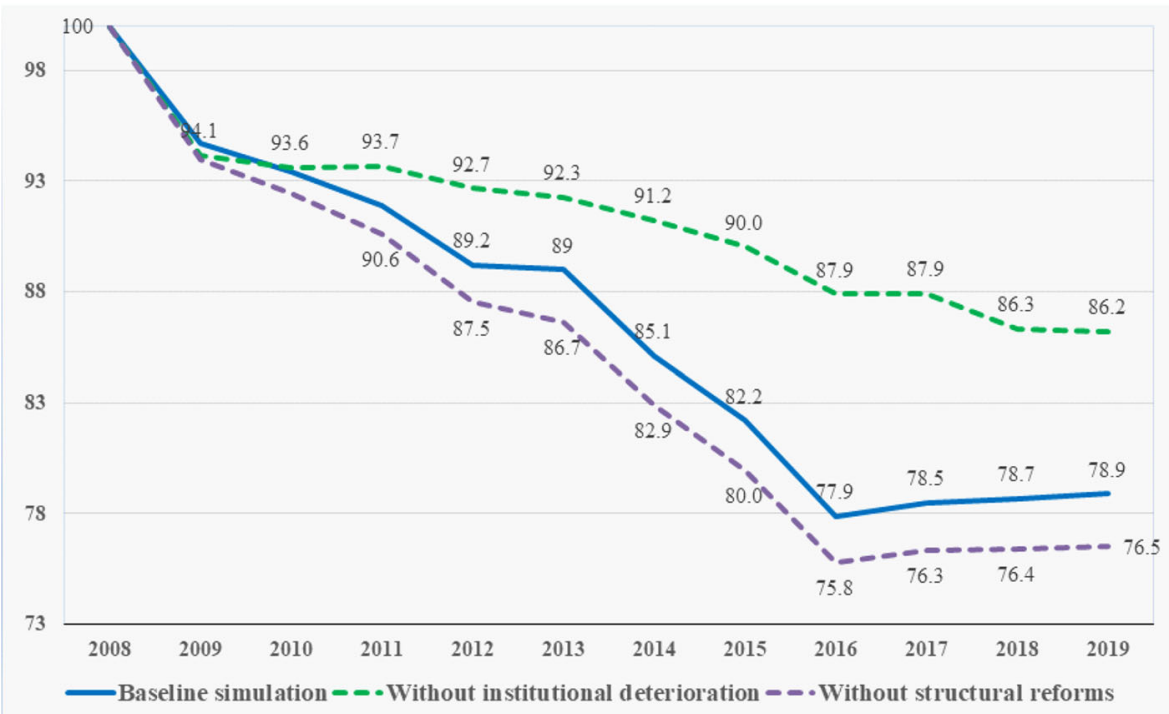

Fig. 2 Output loss and its main drivers 


\subsection{Distributional Effects}

Our solution also allows us to quantify the distributional implications of the aggregate output loss during the debt crisis year. Recall that we have three distinct income groups in the model (capital owners (or "the rich"), private workers and public employees), as modeled in Section 2.2 above. Figure 3 depicts respectively the simulated time paths of the worker's to capital owner's net income ratio and of the public employee's to capital owner's net income ratio over the sovereign debt crisis years (net incomes are defined in Appendix A.7 of the online Appendix). These paths follow by using the model's solution into the budget constraints of the three types of households in Section 2.2.

Inspection of Fig. 3 reveals that, after an improvement at the start of the crisis, the net income gap between workers and capital owners became wider. The same applies to the net income gap between public sector employees and capital owners. Putting them together, these two graphs imply that inequality has worsened, although the big losers from the debt crisis have been the private workers. Their net income has suffered more than that of public employees and, although it has somehow managed to recover after a sharp fall in the early years of the crisis, their share remains below that in the pre-crisis years.

Although we do not have access to actual data so as to compare them to our simulated paths, we believe our results are in line with the widespread belief that the global financial crisis, as well as the policy mix chosen to deal with its effects, has mainly

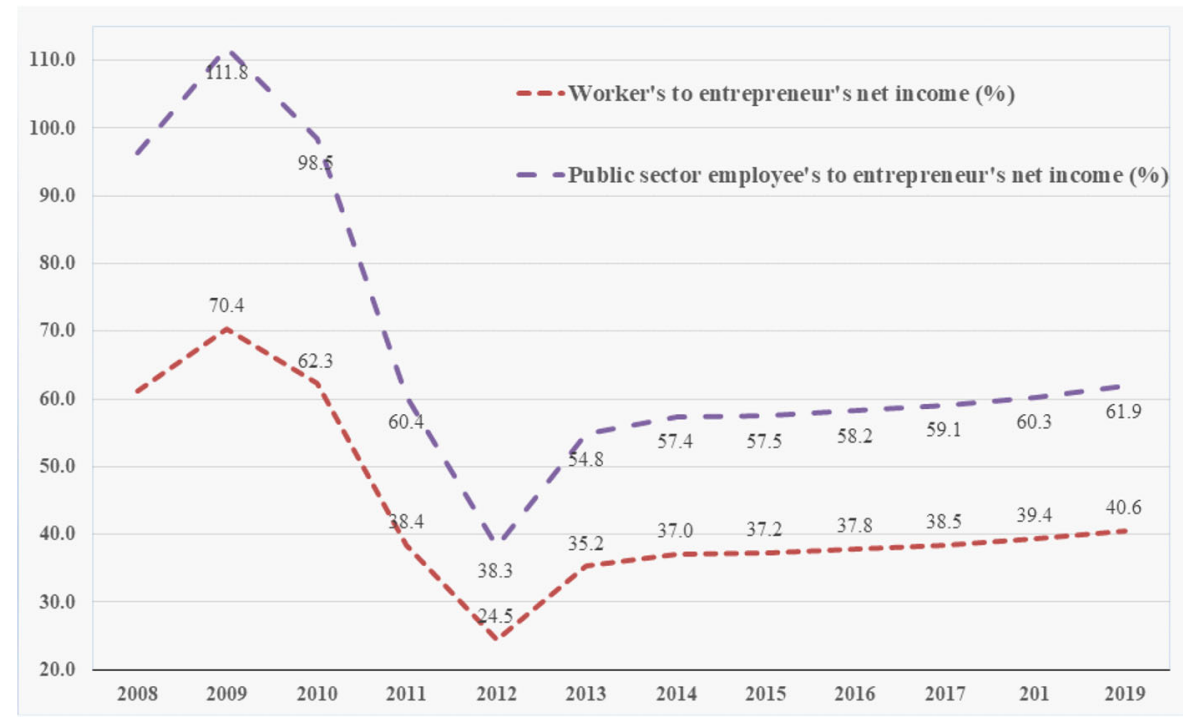

Fig. 3 Distributional effects 
hurt those who are unskilled and work in the private sector (see e.g. Bourguignon (2018) for evidence across several countries).

\section{Counterfactuals Between 2008 and 2019}

In this section, we conduct two types of experiments. First, we consider what would have happened since 2008 without international financial aid. Second, we study what would have happened since 2008 if, given aid, some things had been done a bit better. Recall again that this is without taking into account the covid-19 shock that hit the Greek economy in 2020 .

\subsection{Counterfactuals: It Could Have Been Much Worse}

We first switch off fiscal aid. This is to examine what would have happened if EU states and institutions had not stepped in to repay debt obligations and to purchase the Greek sovereign debt when the country was shut out of the bond market and trust was lost. Say, for example, that the Greek government would have to increase income taxes, $\tau^{y}$, to make up for the loss in public revenue due to setting $\lambda^{e u} \equiv 0$. This experiment is shown in Fig. 4. As can be seen, in this case, the depression would be much deeper and, most probably, would have triggered a severe social unrest.

We have also attempted to switch off TARGET2 balances, which, as we have seen, has been the main form of monetary policy aid from the ECB to Greece. This is to examine what would have happened if the ES, via the Greek NCB, had not followed an accommodative monetary policy towards Greece. In this case, we report that our

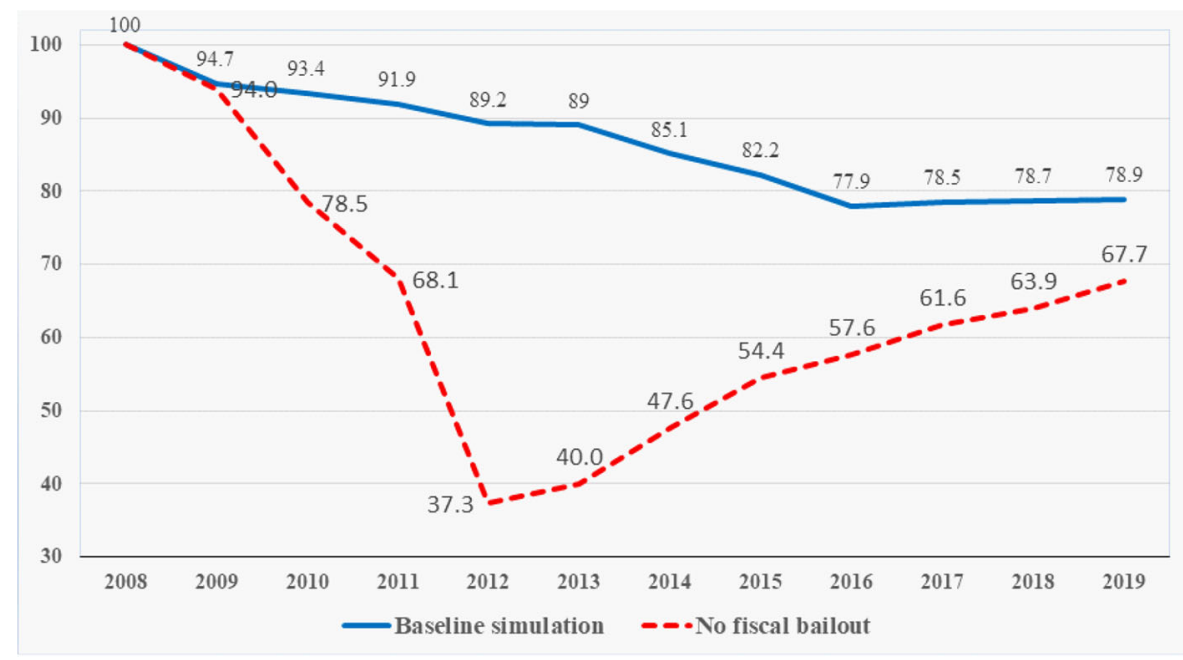

Fig. 4 Counterfactual: No fiscal bailout 


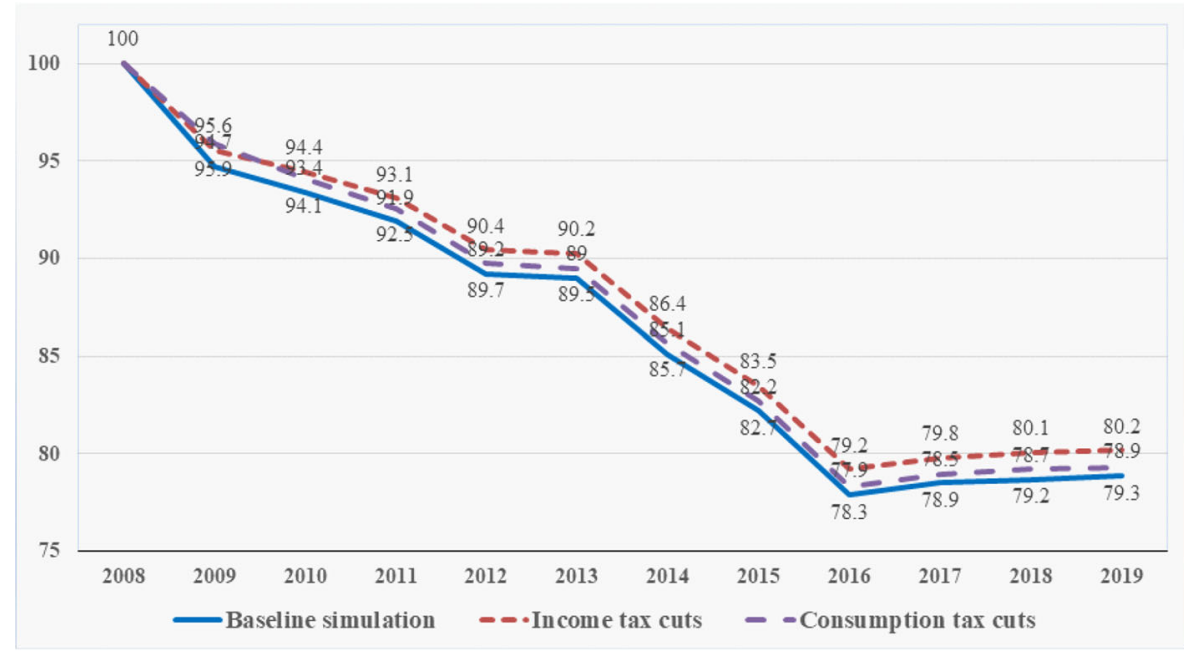

Fig. 5 Counterfactual: Less fiscal austerity - lower taxes

model does not exhibit dynamic stability. ${ }^{45}$ In simple words, we cannot get a solution. This - according to our view - illustrates the important role played by the ECB in the Greek bailout.

\subsection{Counterfactuals: It Could Have Been Much Better}

In this subsection, we restore financial (fiscal and monetary) aid, as in the baseline simulations of Section 4, and examine what would have happened if some things had been done slightly better.

Figures 5 and 6 illustrate respectively the simulated paths of GDP when we assume lower income tax rates and higher public spending other things equal. That is, in these graphs, there is a milder fiscal austerity. In particular, in Fig. 5, we have arbitrarily set the income tax rates 2 percentage points (pp) lower than in the data in each year, while, in Fig. 6, we have arbitrarily assumed that each item of public spending, as share of GDP, is $2 \mathrm{pp}$ higher than in the data in each year. Notice that we change one thing at a time. As can be seen, the output loss would be milder, although the gains are small. Also note that, in these cases, the cut in taxes, or the rise in spending, are like free lunches because any fiscal expansion has been assumed to be accommodated by a rise in TARGET2 liabilities which continue to adjust residually. By contrast, in

\footnotetext{
${ }^{45}$ When we set the change in TARGET2 liabilities exogenously (in this particular counterfactual, equal to zero) another fiscal, or balance-sheet monetary, policy variable has to take its place in the category of endogenous variables. We have experimented with various possibilities. None of them delivers a stable solution over this period if fiscal variables remain as in the data.
} 


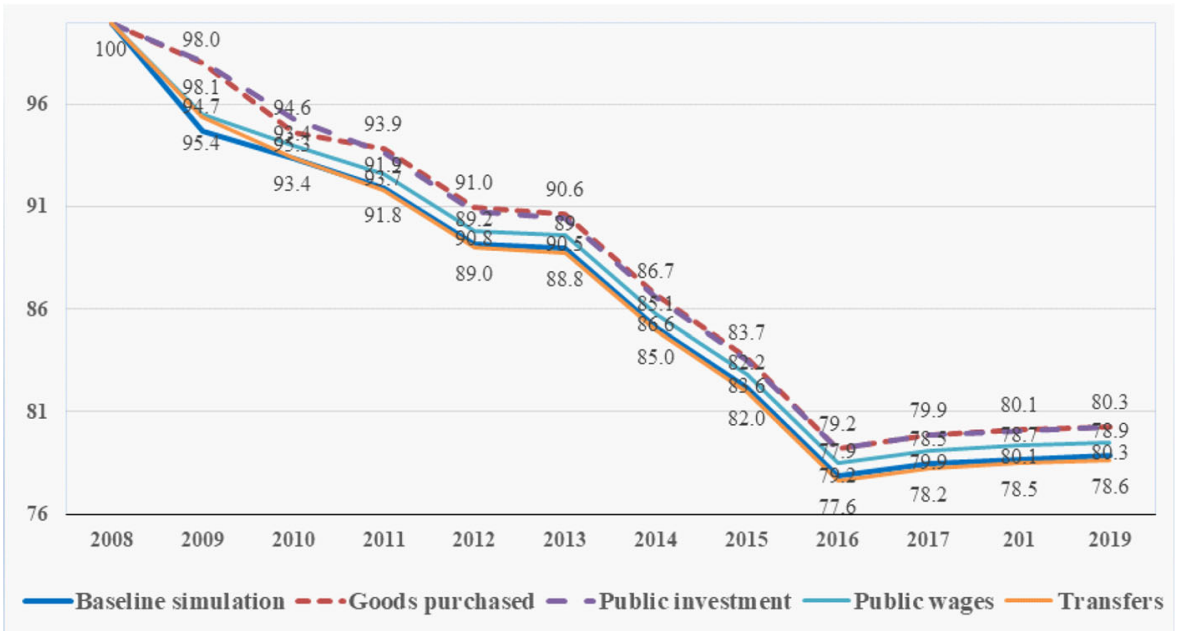

Fig. 6 Counterfactual: Less fiscal austerity - higher spending

Fig. 7, we assume a "budget neutral" fiscal policy mix, in the sense that income tax rates are cut by $2 \mathrm{pp}$ (or public investment, as share of GDP, rises by $2 \mathrm{pp}$ ), but, at the same time, transfers as share of GDP are also cut by $2 \mathrm{pp}$. In this more realistic fiscal scenario, again the output loss would be milder but not by much. In Fig. 8, we assume a stronger liberalization in product markets. In particular, we assume that the Dixit-Stiglitz parameter of product substitutability gets closer to its value in the core

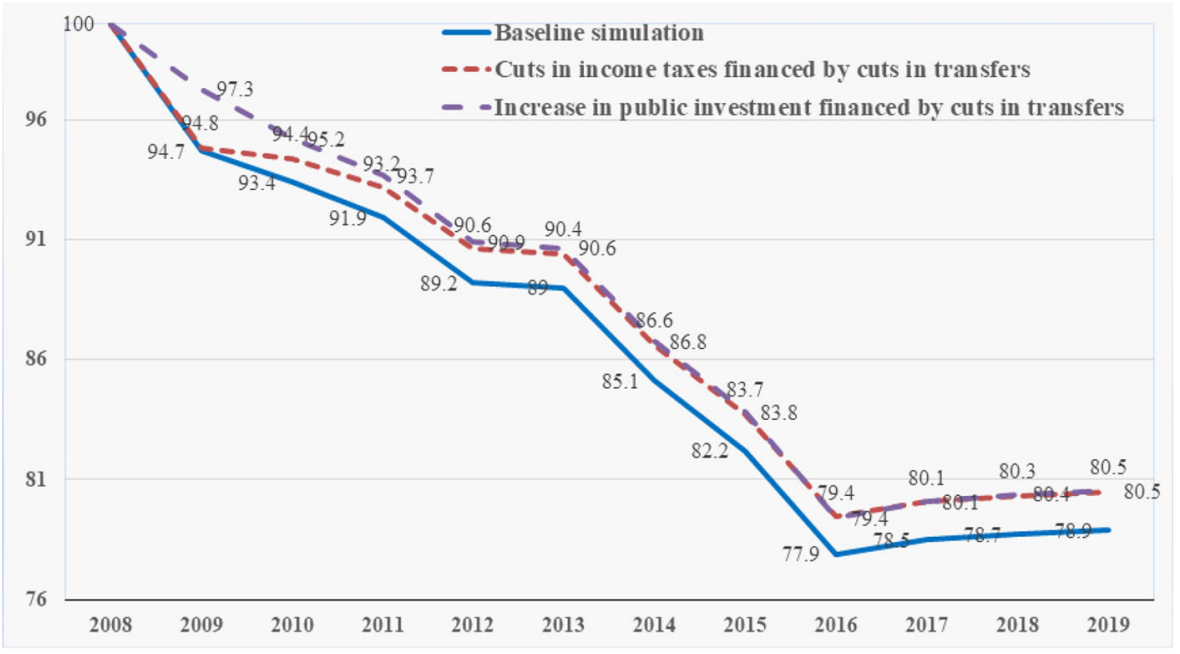

Fig. 7 Counterfactual: Alternative fiscal mixes 


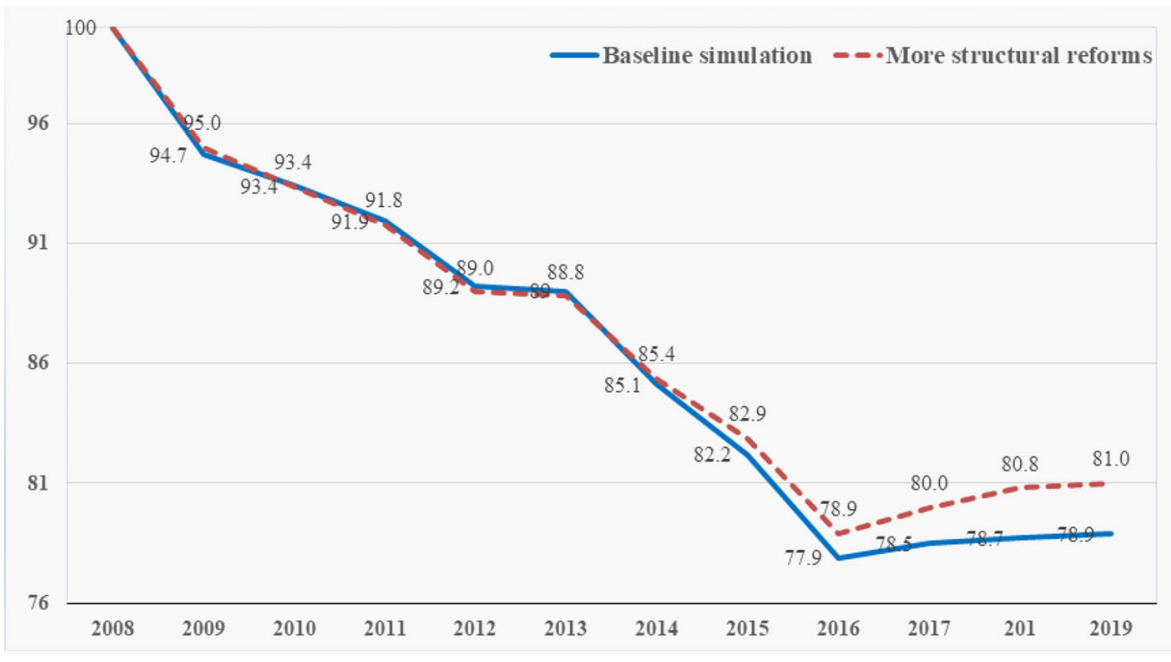

Fig. 8 Counterfactual: Stronger product market liberalization

countries of the EZ (from 0.775 to 0.80 ); these numbers are similar to those used by Eggertsson et al. (2014). Again there is a milder depression but again we cannot see spectacular improvements. Finally, in Fig. 9, we combine the scenaria of Figs. 7 and 8 , and, more importantly, we now set the index of property rights as it it was in the Greek data before the crisis (specifically, we keep $P R_{t}$ constant at its 2009 value for

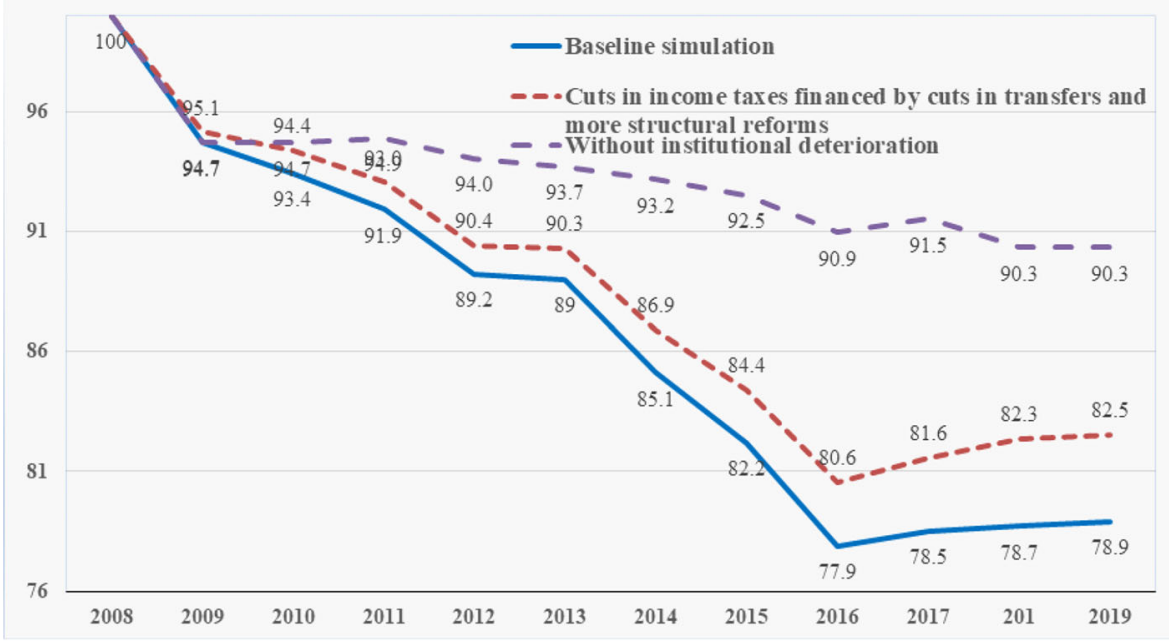

Fig. 9 Putting all counterfactuals together 
ever). ${ }^{46}$ In this case, the output loss would be only $9.1 \%$ (namely, $100-90.9=9.1$ ), which is close to that experienced by other EZ periphery countries. This confirms, once more, the key detrimental role played by institutional deterioration during the Greek depression.

\section{Closing Remarks, Caveats and Extensions}

In this paper, we have provided a detailed anatomy of the Greek sovereign debt crisis by using a medium-scale micro-founded macroeconomic model that incorporated the key features of the Greek economy. The focus was, not only on the role of fiscal austerity, but also on the roles of international aid and institutional quality both of which have been closely associated with fiscal austerity.

Since the main results have already been stated in the Introduction, we close with a discussion of some key assumptions, caveats of the model and possible extensions. First, here, although we incorporated the risk of sovereign debt default, we did not associate it with the risk of exit from the EZ (the so-called fear of Grexit). An extension could be to add the "exit expectation" either as a possible regime switch as in e.g. Kriwoluzky et al. (2019) or ideally as model uncertainty and worst-case scenario as in e.g. Hansen and Sargent (2008). Second, here we modeled institutional quality in a specific way: we assumed that firms can keep a fraction of their output only, with the rest being taken away by rent-seekers, where this fraction was set according to an index measuring the enforcement of property rights. Although this is rather standard in the quantitative macro literature, it is widely recognised that institututional quality is an endogenous state variable shaped by current choices as well as by past investments in state capacity (see e.g. Besley and Persson (2009)). Third, another interesting extension could be to add a core creditor country like Germany, so as to have a closed general equibrium system of the EZ. This would enable us to examine how financial aid given to one country affects the other country and, in particular, how the various fiscal and monetary bailouts provided to Greece have affected the core of the EZ (see e.g. Philippopoulos et al. (2017b) for a related two-region model). We leave these extensions for future work.

Acknowledgments We are grateful to H.-W. Sinn, G. Tavlas and P. Tsakloglou for clarifications and discussions. We thank seminar participants at the European Central Bank (especially, K. Masuch), at the conference on Greece and the Euro at Fletcher School Tufts University (especially, G. Alogoskoufis, N.

\footnotetext{
${ }^{46}$ The deterioration of institutional quality in the period 2008-2016, which is clearly seen in the data, is characterized by two main milestones. The first concerns the violent demonstrations, accompanied by extensive destruction of private property, in the center of Athens, in December 2008. The second concerns the political polarization and lack of political consensus since 2010, which was the year of the first memorandum of understanding offering financial assistance in exchange of fiscal austerity and structural reforms (the so called economic adjustment program). All these developments, fuelled by political commentators, led to strikes, protests, etc, which further deteriorated institutional quality and undermined economic confidence and sentiments. In this scenario, where we investigate what would have happened if the quality of institutions had not been deteriorated, we assume that institutional quality remains at its 2009 value and not at its 2008 one, because the events of 2008 preceded the economic adjustment program and its implications.
} 
Christodoulakis, Y. Ioannides and L. Papademos) and at the Hellenic Observatory of the LSE (especially, V. Monastiriotis and an anonymous reviewer). We have also benefited from discussions with T. Christou, H. Dellas, V. Dimakopoulou, S. Jafarey, E. Louri, S. Sakkas, P. Varthalitis and V. Vassilatos. We thank K. Michou at the Bank of Greece for help with the data. George Economides and Apostolis Philippopoulos are grateful to the Hellenic Observatory of the LSE for financial support of a project on Economic growth in Greece: Barriers and prospects to which this paper belongs (we specifically acknowledge the support of The A. C. Laskaridis Charitable Foundation (ACLCF), Dr Vassili G. Apostolopoulos and the LSE). Dimitris Papageorgiou wishes to clarify that the views expressed herein do not necessarily express the views of the Bank of Greece. Any errors are our own.

Supplementary Information The online version contains supplementary material available at (10.1007/s11079-020-09613-3)

\section{References}

Acemoglu D (2009) Modern economic growth. Princeton University Press, Princeton

Alesina A, Favero C, Giavazzi F (2019) Austerity. Princeton University Press, Princeton

Alogoskoufis G (2019) Greece and the Euro: a Mundellian tragedy, CGK Working Paper no. 2019-01, Fletcher School, Tufts University, Boston

Angelopoulos K, Philippopoulos A, Vassilatos V (2009) The social cost of rent seeking in Europe. European J Polit Econ 25:280-299

Arellano C, Bai Y (2016) Fiscal austerity during debt crises, Minneapolis Fed Research, Staff Paper no. 525, Minneapolis

Ball L, Romer D (1990) Real rigidities and the non-neutrality of money. Rev Econ Stud 57:183-203

Bassetto M, Sargent T (2020) Shotgun wedding: Fiscal and monetary policy, NBER Working Paper, no 27004, NBER

Benigno P, Eggertsson G, Romei F (2014) Dynamic debt deleveraging and optimal monetary policy, NBER Working Paper, no. 20556, NBER

Benigno P, Nistico S (2017) Non-neutrality of open market operations, mimeo

Besley T, Persson T (2009) The origins of state capacity: Property rights, taxation and politics. Am Econ Rev 99:1218-1244

Besley T, Ghatak M (2010) Property rights and economic development. In: Rodrik D, Rosenzweig M (eds) Handbook of development economics, vol 5, North-Holland

Blanchard O, Gali J (2007) Real wage rigidities and the new Keynesian model. J Money Credit Bank $39: 35-65$

Bourguignon F (2018) World changes in inequality: An overview of facts, causes, consequences and policies. CESifo Econ Stud 64:345-370

Bournakis I, Tsoukis C, Christopoulos D, Palivos T (2017) Political economy perspectives on the Greek crisis. Palgrave Macmillan, London

Chodorow-Reich G, Karabarbounis L, Kekre R (2019) The macroeconomics of the Greek depression, mimeo

Christou T, Philippopoulos A, Vassilatos V (2020) Institutions and macroeconomic performance: Core vs periphery countries in the Eurozone, mimeo, Department of Economics, Athens University of Economics and Business

Coenen G, Karadi P, Schmidt S, Warne A (2018) The new area-wide model II: An extended version of the ECB's micro-founded model for forecasting and policy analysis with a financial sector, European Central Bank, Working Paper, no. 2200

Corsetti G, Kuester K, Meier A, Muller G (2013) Sovereign risk, fiscal policy and macroeconomic stability. Econ J 123:F99-F132

Curdia V, Woodford M (2011) The central-bank balance sheet as an instrument of monetray policy. J Monet Econ 58:54-79

Dellas H, Malliaropoulos D, Papageorgiou D, Vourvachaki E (2017) Fiscal policy with an informal sector, Bank of Greece, Working Paper no 235

De Grauwe P (2016) Economics of monetary union, 11th edn. Oxford University Press, Oxford

Dixit A (2004) Lawlessness and economics. Princeton University Press, Princeton

Drazen A (2000) Political economy in macroeconomics. Princeton University Press, Princeton 
Economides G, Papageorgiou D, Philippopoulos A (2017) The Greek great depression: a general equilibrium study of its main drivers. In: Bournakis I, Tsoukis C, Christopoulos D, Palivos T (eds) Political economy perspectives on the Greek crisis. Palgrave Macmillan

Eggertsson G, Ferrero A, Raffo A (2014) Can structural reforms help Europe? J Monetary Econ 61:2-22

Esteban J, Ray D (2011) Linking conflict to inequality and polarization. Am Econ Rev 101:1345-1374

Garin J (2015) Borrowing constraints, collateral fluctuations and the labor market. J Econ Dyn Control 57:112-130

Gertler M, Karadi P (2011) A model of unconventional monetary policy. J Monetary Econ 58:17-34

Gertler M, Kiyotaki N (2010) Financial intermediation and credit policy in business cycle analysis. In: Friedman B, Woodford M (eds) Handbook of monetary economics, vol 3A, North-Holland

Gibson H, Hall S, Tavlas G (2015) The effectiveness of the ECB's Asset Purchasing Programs of 2009 to 2012, Working Paper no. 15/24, Department of Economics, University of Leicester

Gibson H, Hall S, Petroulas P, Tavlas G (2019) The effect of emergency ELA on bank lending during the euro area crisis, Working Paper no. 19/01, Department of Economics, University of Leicester

Glomm G, Jung J, Tran C (2018) Fiscal austerity measures: Spending cuts vs. tax increases. Macroecon Dyn 22:501-540

Gourinchas P-O, Philippon T, Vayanos D (2017) The analytics of the Greek crisis. NBER Macroecon Ann $31: 1-81$

Guntner J (2015) The federal funds rate, excess reserves and unconventional monetary policy. J Econ Dyn Control 53:225-250

Hansen LP, Sargent T (2008) Robustness. Princeton University Press, Princeton

Hillman A (2009) Public finance and public policy, 2nd edn. Cambridge University Press, Cambridge

Hull J (2015) Risk management and financial institutions, 4th edn. Wiley, Hoboken

Ioannides Y, Pissarides C (2015) Is the Greek crisis one of supply or demand? Brooking Pap Econ Activ 46:349-373

Kollintzas T, Papageorgiou D, Tsionas E, Vassilatos V (2018) Market and political power interactions in Greece: an empirical investigation. IZA J Labor Pol 7:1-43

Korinek A, Simsek A (2016) Liquidity trap and excessive leverage. Am Econ Rev 106:699-738

Kriwoluzky A, Muller G, Wolf M (2019) Exit expectations and debt crises in currency unions. J Int Econ 121:1-13

Lansing K (2015) Asset pricing with concentrated ownership of capital and distribution shocks. Am Econ J Macroecon 7:67-103

Lorenzoni G (2014) International financial crises. In: Gopinath G, Helpman E, Rogoff K (eds) Handbook of international economics, vol 4, North-Holland

Masuch K, Anderton R, Setzer R, Benalal N (2018) Structural policies in the euro area, Occasional Paper Series, no. 210, European Central Bank

Meghir C, Pissarides C, Vayanos D, Vettas N (2017) Beyond austerity: reforming the Greek economy. MIT Press, Cambridge

Miao J (2014) Economic dynamics in discrete time. MIT Press, Cambridge

Murphy K, Shleifer A, Vishny R (1991) The allocation of talent: implications for growth. Quart J Econ:503-530

Papageorgiou D, Vourvachaki E (2017) Macroeconomic effects of structural reforms and fiscal consolidation: trade-offs and complementarities. European J Polit Econ 48:54-73

Papaioannou E (2016) Eurozone original sin? Nominal rather than institutional convergence. In: Baldwin R, Giavazzi F (eds) The Eurozone crisis. A VoxEU.org ebook, CEPR, London

Perotti R (2020) Understanding the German criticism of the target system and the role of central bank capital, NBER Working Paper, no. 27627, NBER, Cambridge, Mass

Persson T, Tabellini G (2000) Political economics. MIT Press, Cambridge Mass

Philippopoulos A, Vassilatos V, Varthalitis P (2017a) Fiscal consolidation in an open economy with sovereign premia and without monetary policy independence. Int J Central Bank 13:259-306

Philippopoulos A, Vassilatos V, Varthalitis P (2017b) Fiscal consolidation and its cross-country effects. J Econ Dyn Control 83:55-106

Reis R (2013) The mystique surrounding the central bank's balance sheet applied to the European crisis. Am Econ Rev Papers Proc 103:135-140

Reis R (2017) Can The central bank alleviate fiscal burdens? CESifo Working Paper, no. 6604-2017. In: Mayes, Siklos, Sturm (eds) Published in the economics of central banking. Oxford University Press

Reis R (2019) The second decade of the euro: old challenges in new clothes, ECB Sintra Forum

Schmitt-Grohé S, Uribe M (2003) Closing small open economy models. J Int Econ 61:163-185 
Sims E, Wu JC (2020) Evaluating central banks' tool kit: past present and future, mimeo

Sinn H-W (2010) Rescuing Europe. CESifo Forum 11:1-22

Sinn H-W, Wollmershauser T (2012) TARGET loans, current account balances and capital flows: The ECB rescue facility. Int Tax Public Finance 19:468-508

Sinn H-W (2014) The Euro trap. Oxford University Press, Oxford

Tavlas G (2019) The theory of monetary integration in the aftermath of the Greek financial crisis, The seventh annual Marco Minghetti lecture, with comments by P. C. Padoan and P. Savona, Instituto Luigi Struzo, Rome

Tullock G (1980) Efficient rent-seeking. In: Buchanan JM, Tollison RD, Tullock G (eds) Toward a theory of the rent-seeking society. Texas A\&M University Press, College Station

Uribe M, Schmitt-Grohé S (2017) Open economy macroeconomics. Princeton University Press, Princeton

Wallace N (1981) A Modigliani-Miller theorem for open market operations. Am Econ Rev 71:267-274

Walsh C (2017) Monetary theory and policy, 4th edn. MIT Press, Cambridge

Whelan K (2014) TARGET2 and central bank balance sheets. Econ Pol:79-137

Whelan K (2017) Should we be concerned about TARGET balances?, Directorate-General for Internal Policies, Policy Department A, Economic and Scientific Policy, IP/A/Econ/2017/-04, European Parliament

Publisher's Note Springer Nature remains neutral with regard to jurisdictional claims in published maps and institutional affiliations. 